(C) 2020 Anastasiia Khmel and Iryna Tykhonenko. This is an open access article licensed under the Creative Commons Attribution-NonCommercial 4.o International License

(https://creativecommons.org/licenses/by-nc/4.o/)

\title{
Latin American Direction of Ukrainian Economic Diplomacy: The Overview of Successes and Failings
}

\author{
Anastasiia Khmel \\ Petro Mohyla Black Sea National University, \\ Mykolaiv, Ukraine \\ Iryna Tykhonenko \\ Petro Mohyla Black Sea National University, \\ Mykolaiv, Ukraine
}

Doi: 10.36941/ajis-2020-0oo4

\begin{abstract}
In the article, the authors analyzed successes and failings of the Ukrainian economic diplomacy in Latin America region. Such results were achieved by analyzing the degree of scientific investigation the possibilities, features and basic characteristics of economic diplomacy by contemporary Ukrainian and foreign researchers, as well as by analyzing the websites of Ukrainian embassies in Latin American countries and using the information of the State Statistics Service of Ukraine and mass media. Researchers drew attention to the peculiarities of economic relations between Ukraine and Latin America countries. It has been found that bilateral relations between Ukraine and Latin American countries are generally poorly developed, the embassies of Ukraine exist only in five countries: Mexico, Cuba, Argentina, Brazil and Chile, and these embassies in turn represent Ukraine's national interests in 15 other Latin American countries. Ukraine has the most well-established economic relations with the first five above-mentioned countries as a result of economic diplomacy. It was concluded that Ukrainian economic diplomacy has some achievements (the developing of volume of export-import operations between Ukraine and all regional countries, except Cuba, and the opening of the honorary consulate in Chile) and failings (the lack of diplomatic missions in all LA countries, problems with updating information on planned activities in the economic sphere (2015, 2016) on the embassies' web-site, negative trade balance for Ukraine).
\end{abstract}

Keywords: economic diplomacy, Ukraine, Latin American countries, Brazil, Argentina

\section{Introduction}

The economic factor is a significant component of the country's development, its positioning on the international arena and becomes one of the indicators of country's power. Ukraine is no exception, being under the influence of modern world processes such as economic globalization, as all other countries in the world. Therefore, the question of the effectiveness of using such an instrument as economic diplomacy in the implementation of foreign policy is actually on time for our country. It is worth pointed out that the content and forms of economic diplomacy are differ depending on several aspects, firstly, the level of economic development of the state that implements it and secondly, the development of the state that becomes the object of such influence. Therefore, it is important for Ukraine to develop appropriate methods and approaches that can be used by Ukrainian Embassy staff to implement the country's economic policy on a regional and global scale of international economic relations. 
The question about the level of effectiveness of Ukrainian economic diplomacy and its forms of implementation, in particular in Latin America region, is raised, because of the importance and attractiveness of this region for Ukraine and its foreign economic activity. A significant factor in the development of bilateral cooperation between Ukraine and Latin American countries is the presence of a large Ukrainian diaspora in some of them. In turn, at the diplomatic level, the system of diplomatic missions of Ukraine, especially embassies and consulates, in this region is not high developed, that is one of the factors of low level of economic cooperation between the countries of the region and Ukraine.

In our opinion, the economic direction of work of diplomatic service of Ukraine in Latin America region is ineffective, because apart from low bilateral trade indicators, we also noticed that Latin American countries are not involved in concerted foreign economic activities, in particular, in support of anti-Russian sanction, because of annexation of Crimea, war on the East of Ukraine since 2014. For instance, none of the Latin American countries has supported sanctions against the Russian Federation (except the dependent French territory - Guyana). Note that Ukraine does not develop mechanisms of economic diplomacy in the Latin American region and, as a result the potential of bilateral economic relations with the countries of the region are not used with all strength.

\section{Literature Review, Theoretical and Methodological Framework}

Our research topic is at the intersection of such disciplines as the basics of diplomacy, foreign policy, international economic relations and represents the importance and relevance in the modern day. There are enough scientific publications on various aspects of the outlined topic, but at the same time, a comprehensive analysis has not yet been implemented.

Thus, the existing publications reveal several aspects of a problem of investigation. Firstly, the theoretical aspects of economic diplomacy. In particular, the Swiss researchers Raymond Saner and Lichia Yiu (2003) analyze the peculiarities and basic characteristics of economic diplomacy in contemporary international economic relations. Secondly, there are studies that reveal the importance of economic diplomacy for the security of the country. This trend is the subject of research by Armenian scientist Tatoul Manasserian. In his paper, "Economic Diplomacy: From Theory to Real Life" (2017), he noted that in order to counteract external economic threats, the direction and programs of economic diplomacy should be clearly defined.

Thirdly, scholars analyze the advantages and disadvantages of economic diplomacy in individual countries, which can be used by the country as a certain experience. In particular, Juma Calestous (2013) drew attention to the fact that relations between Africa and Brazil are not based on historical and cultural background, but rather the result of serious diplomatic efforts by both countries. The scientist noted that Brazilian President Luis Inacio Lula da Silva has visited Africa more than 20 times and set up 19 new embassies across Africa, and in 54 African countries exists 37 Brazilian embassies. The example shows that, as Brazil's embassies increase, trade volumes have grown from \$ 1.5 billion to \$ 9 billion. Maria Ewa Szatlach (2015) works in the same direction, describing the importance of economic diplomacy in China. In her article, a considerable number of results of studies on the economic diplomacy of Paul Bozhik and Jan Rimarczyk are systematized. It is noted that economic diplomacy includes a wide range of economic and political instruments. The researcher attached great importance to the factor of economic sanctions (Szatlach M. E., 2015).

A fourth group of scholars are working on strategies and tools of economic diplomacy. Thus, N. Bayne and S. Woolcock (2003) note that the importance of economic diplomacy has increased to such level that national governments need to investigate three important issues: relations between politics and economy, relations between national and international interests, relations between government and others participants in international economic relations. They describe four interconnected strategies of economic diplomacy: involving high-level politicians (ministries) in their activities, involving non-governmental organizations, private business and civil society in the creation of this diplomacy. They draw our attention to trade and corporate forms of diplomacy as 
forms of economic diplomacy.

The next group of scholars describe the tools of economic diplomacy. D. Lee and B. Hocking (2010) outline the goals of economic diplomacy, which are commonly pursued in bilateral, regional or multilateral negotiations, often achieved through five tools: advising national economic entities, assisting businesses in penetrating foreign markets, agreeing favorable rules and regulations for international trade and foreign investment, conducting external market research, preventing conflicts between different economic actors from different countries. Analyzing China's experience of economic diplomacy, D. Brautigam and T. Xiaoyang (2012) note that while free trade zone (FTZ) is a major tool for Chinese economic diplomacy in Asia, Europe, and the Americas, economic diplomacy in many developing African countries takes other forms. In response to access to natural resources, China provides money and builds roads, railways, airports, bridges, military facilities, hospitals, sports stadiums and office buildings in African countries. In this case, China's economic diplomacy has embodied the so-called "soft power" of the state in international relations.

The sixth group of researchers pays attention to the international importance of economic diplomacy. Russian researcher T.M. Isachenko (2015) explores the relevance of defining the role of economic diplomacy in resolving or deepening political contradictions in the international arena. Ukrainian researchers also have investigations in this area, in particular Z. S. Varnaliy (2016), K. Flissak (2013), N. O. Tatarenko (2005), but at this stage the successes and miscalculations of Ukraine's economic diplomacy especially in the Latin American direction were not analyzed. That is why the topic of our research is relevance for Ukrainian science.

Above-mentioned studies and sources provided the theoretical and methodological basis for the study. Firstly, the corresponding quantitative and statistical data was used to describe the activities of diplomatic missions of Ukraine in Latin American countries and to determine the level of effectiveness of their work. Secondly, based on the systematization of trade and economic statistics of cooperation between Ukraine and the countries of the region were revealed failings of Ukraine, especially in the sphere of investment.

Therefore, the authors had the aim to systematize the theoretical value of the importance of economic diplomacy of the state and extrapolate them to the development of economic diplomacy of Ukraine exclusively in the Latin American direction. Based on the analysis of available statistics on the economic relations of Ukraine with Latin American countries and the state of information content of the web-sites of Ukrainian embassies in the Latin American countries as agents of foreign economic activity of Ukraine abroad, the authors attempted to find out the successes and failings of economic diplomacy of Ukraine in Latin American direction.

\section{Theoretical Basic of Ukrainian Foreign Economic Policy: Latin America Region as the Object}

Before we will reveal the importance of Latin American countries to Ukraine, we should dwell on the term "Latin America". It is interpreted either on the basis of geographical location or socio-political content. So, from a socio-political perspective, Latin America is synonymous with the concept of Ibero-America, and generally includes the territories of America dominated by Spanish or Portuguese languages: Mexico, most of Central America (Nicaragua, Honduras, Costa Rica, Guatemala, El Salvador, Panama, Belize), South America (Argentina, Bolivia, Brazil, Venezuela, Guyana, Colombia, Paraguay, Peru, Suriname, Uruguay, Chile, Ecuador) and the Caribbean (Cuba, Dominican Republic, Haiti, Jamaica, St. Kitts and Nevis, Antigua) and Barbuda, Bahamas, Dominica, Saint Lucia, Saint Vincent and the Grenadines, Grenada, Barbados, Trinidad and Tobago). We will use this understanding of term "Latin America" as a region in international relations according to classification of United Nations Organization (UN. Country classification).

There are 33 countries and 4 dependent territories in Latin America: French Guiana, Guadeloupe, Martinique, Puerto Rico. The region has $20 \%$ of the world's natural resources, including oil and gas, fresh water reserves, large areas and favorable conditions for agricultural production. For 
Ukraine, Latin America is entering a large and promising market with half a billion populations, foreign trade volume of over $\$ 600$ billion. The total gross domestic product (GDP) of the region is about \$ 2 trillion (Kukharenko R., 2016). Latin American markets are capacious, dynamic, and countries in the region are committed to developing technical and technological cooperation (space programs, technology delivery, exploration, environmental protection, investment cooperation). Therefore, the development of economic relations between Ukraine and Latin America is perspective, especially in technical and technological directions.

The Ukrainian researcher V.M. Nyzhnyk (2007) noted the following important features of economic activity in cooperation with Latin American countries: systematicity, dynamism and commitment, focus on increasing the supply of high-tech export products. That is why, economic policy should be thought out, planned in accordance with macroeconomic development trends, with improved information support for the promotion of Ukrainian competitive goods and services, economic projects in existing and new markets. Optimization of the activities of bilateral intergovernmental commissions on trade and economic cooperation (or their creation, if they are nor existing), and the use of regional economic organizations' opportunities to promote the interests of Ukrainian business are an important aspect according to the researcher. Business, in its turn, should participate regularly in international business forums and fairs (Nyzhyk, 2007). At the same time, we would like to emphasize that Ukrainian enterprises, that are capable of operating in the foreign economic market, are not properly prepared for entering the Latin American markets.

It is worth pointing out that Ukraine does not have a single regulatory document in which the state's economic strategy is formed. But the elements of the foreign economic policy of the state are enshrined in the "Sustainable Development Strategy "Ukraine 2020" (Presidential Decree on Ukraine 2020 Sustainable Development Strategy, 2015), the Law of Ukraine "On National Security" of June 21, 2018 (Law of Ukraine On National Security of Ukraine, 2018), and the Law of Ukraine "On Basic Directions of the Internal and External Policy of Ukraine" of July 1, 2010 with amendments of 2014, 2015, 2018, 2018 years (Law of Ukraine On the Principles of Domestic and Foreign Policy, 2018). In particular, the economic goals of Ukraine's foreign policy include: protection of the economic interests of the country and the rights of business entities in the host country; facilitating the development of trade and economic relations, attracting foreign investment in priority sectors of the economy and the implementation of international agreements of the country concluded with the host country.

An important feature of nowadays world market is that states and international organizations are not a single producers of economic diplomacy, but also regional economic and financial organizations, specialized institutions, private companies and non-governmental organizations (chamber of commerce, business unions), individuals, legal entities, etc., the number of which is constantly increasing. Ukrainian researcher N. O. Tatarenko (2005) notes that "the state seeks to retain institutional instruments of regulation at least in the sphere of foreign economic activity" ( $\mathrm{N}$. O. Tatarenko, 2005, pp. 7-8). Thus, Ukrainian embassies (there are only 5 in LA!) are designed to promote the state's external interests primarily in such dimensions as trade and investment, protection of the interests of national companies, and co-operation in the field of scientific and technical cooperation and tourism.

The authors take these aspects as determinants of consideration of Ukraine's economic diplomacy in the Latin American direction. In the context of revealing the successes and failings of Ukraine's economic diplomacy, the level and status of the informational content of the web-site of the embassies of Ukraine in Latin America was identified as determinant of this article. Such informational and promoting work of embassy in the 21st century, has a significant role in international relations and becomes a component of the country's foreign policy course as so-called electronic diplomacy. Kyiv's relations with Latin American countries are also conditioned by the presence of a large Ukrainian diaspora in the region, which has a direct impact on the development of economic relations at the bilateral level. 


\section{Successes and Failings of Ukraine-Latin America Economic Relations: The Overview of Ukraine Embassies' Work}

Ukraine in Latin America region has 5 embassies representing Ukraine's national interests in a number of other Latin America countries. The cooperation with these countries and the work of embassies of Ukraine in them will be critically analyzed, especially:

- Argentina (the Embassy of Ukraine in Argentina represents Ukraine's interests in Paraguay, Uruguay and Chile);

- Brazil (the Embassy represents Ukraine's interests in Bolivia, Guyana and Suriname);

- Mexico (the Embassy represents Ukraine's interests in Costa Rica, Guatemala, Panama and Belize);

- Cuba (the Embassy represents Ukraine's interests in Venezuela, Dominican Republic)

- Peru (the Embassy represents Ukraine's interests in Ecuador and Colombia).

As a result, Ukrainian diplomacy works only in 19 countries of Latin America, in other countries Ukraine's interests are not represented at all, neither economic nor political aspects. According to statistics from the State Statistics Service of Ukraine, such passivity of Ukraine in the Latin American market has its negative consequences - low volume of foreign economic relations and trade. However, we have to admit that evolution of Ukrainian-Latin America relations has success and a background for future economic cooperation as well.

\section{The Embassy of Ukraine in Argentine Republic}

Ukrainian-argentine relations. On September 25, 2013, Yuri Dyudin was appointed as Ambassador Extraordinary and Plenipotentiary of Ukraine to the Republic of Argentina, and on July 7, 2015, he was appointed as Non-resident Ambassador of Ukraine to the Republic of Chile, the Eastern Republic of Uruguay and to the Republic of Paraguay. As a result, at the website of the Embassy of Ukraine in Argentina, we can find the information about Ukraine's cooperation with the countries mentioned above. Analyzing the level of information content of the site was concluding several aspects. Web-site does not update in time, because the contract base and the list of documents was updated in July 2012 (Embassy of Ukraine in the Argentine Republic [EUAR], 2019). In contrast, political cooperation has a modern informative content updated in February 2019 (EUAR. Political relations between Ukraine and Argentina, 2019).

The negative balance for Ukraine in trade and economic cooperation with Argentina can be admitted in recent years. Ukraine's exports to Argentine consist of such goods as ferrous metals (76.6\%); electric machines (10.9\%); nuclear reactors, boilers, machines (5.1\%); plastics, polymeric materials (2.8\%). Ukraine imports such goods: fish and crustaceans (21.7\%); seeds and fruits of oilseeds (17.9\%); edible fruits and nuts (15.5\%); tobacco and industrial tobacco substitutes (15.3\%); nuclear reactors, boilers, machinery (13.7\%); pharmaceutical products (3.1\%). As a result, the balance of bilateral trade in goods with Argentina in 2018 remained negative for Ukraine and amounted to \$ 53.32 million (EUAR. Trade and economic cooperation between Ukraine and Argentina, 2019).

Trade and economic cooperation between Ukraine and Argentina is developing at the regional level as well. For instance, five documents on cooperation between Ukrainian regions (Lviv, Ternopil, Kharkiv, Volyn, Khmelnytsky) and partner Argentinean provinces and one transaction about the establishment of friendly ties between the cities of Kiev and Buenos Aires had been signed till 2019 (EUAR Interregional cooperation between Ukraine and Argentina).

Argentina is one of the five countries with the most numerous Ukrainian diaspora, and we agree with the opinion of the Ukrainian Researcher O. Kolada, that "this potential has not been used in full" (O. Kolada, 2018, pp. 38).

Successful economic diplomacy may be preceded by cultural diplomacy and we drew attention to the cultural-humanitarian cooperation between Ukraine and the Argentine Republic. More than 70 events of cultural and educational character take place in Buenos Aires every year (EUAR. Cultural 
and humanitarian cooperation between Ukraine and the Argentine Republic).

However, in our opinion Ukrainian diplomacy does not use in all strength its opportunities, for instance, such positive factor as large diaspora of Ukrainians in Argentina.

The Republic of Chile. Ukraine opened the Embassy of Ukraine in the Republic of Chile only on March 10, 2018 (Ukraine opened the first diplomatic mission in Chile, 2018).

According to the State Statistics Service of Ukraine, in 2017, the trade turnover between Ukraine and Chile amounted to $\$ 42$ million (EUAR. Trade and economic cooperation between Ukraine and Chile), including export $-\$ 3.76$ million (-4.3\%), import $-\$ 38.24$ million (+12.9\%). The trade surplus for Ukraine was \$ 34.48 million. In 2017, Ukraine exported to Chile: nuclear reactors, boilers, machinery (32.6\%); furniture (22.9\%); electric machines (15.5\%); plastics, polymeric materials (3.9\%). Ukraine imported such goods as: seeds and fruits of oilseeds (38.4\%); products from meat, fish $(20,2 \%)$; fish and crustaceans (9.7\%).

The successes of economic diplomacy are significant in cooperation with Chile. For example, the participation of Ukrainian enterprises in the International Exhibition of Military and AviationSpace Engineering FIDAE 2018 (Santiago, April 3 to April 8, 2018) is an important opportunity for intensification of bilateral cooperation in the aerospace industry and military-technical sphere. The work of the Ukrainian-Chilean Chamber of Commerce and Tourism, which was established in February 2018, is facilitated by the intensification of bilateral trade and economic cooperation.

The transportation of cargo from Chile to Bolivia by the Ukrainian Plane An-225 "Mriya" is the obvious example of the expansion of economic cooperation between Ukraine and Latin America countries (Plane giant "Mriya" has implemented a record project of transportation in South America, 2018). Thus, during each flight, the aircraft delivered a cargo weighing 160 tons, carrying 12 large generators in South America with 12 flights. Ukrainian aircraft delivered equipment for the new Bolivian Thermal Power Plant as part of the energy project at the request of the company Hansa Meyer Global Transport GmbH \& Co. After completing one of such flights, "Mriya" landed in Brazil, which caused great enthusiasm among the local population. Such action can be understood as advertising campaign and was an element of both economic diplomacy and PR campaign of our country's image (The legendary plane "Mriya" has returned to Ukraine after the longest business trip, 2018).

The level of cultural and humanitarian cooperation between Ukraine and Chile is very low (EUAR. Cultural and humanitarian cooperation between Ukraine and the Chile). We can notice that a few contacts and events in this direction took place in the late 9o's of the 2oth century, then at the beginning of the first years of the XXI century, followed by a break until 2013, then again 4 years of silence and already in the last quarter of 2017. A number of artistic events were organized under the patronage of the Department of the Embassy of Ukraine in the Argentine Republic in the Republic of Chile with the participation of Ukrainian cultural figures, which significantly improved the image of Ukraine in Chile.

The web-site of the Argentine Embassy in Ukraine represents more information about the news and facts of the sphere of culture and less economics. At the same time, an Argentinian home in Ukraine has been created in Ukraine, where Ukrainians can visit different events every week with the purpose to understand the Argentinean culture better (The official page "Argentina house in Ukraine" in Facebook). There are Days of Argentine Culture in Ukraine (though the program of these days is painted up to 2012 on the page of Argentine Embassy in Ukraine) (La Embajada de la República Argentina en Ucrania. (n.d.). Programa_Dias de la Cultura Argentina in Kiev). In 2016, in Argentina (Buenos Aires) was held «Argentina business \& investment forum», and information on this had been disseminated in Ukraine (La Embajada de la República Argentina en Ucrania, 2016). The fact that the data of the Argentine Embassy in Ukraine are outdated and not updated indicates a loss of interest in conducting cultural and economic events in our country.

The Oriental Republic of Uruguay. The analysis of the development of Ukrainian-Uruguayan relations shows a low level of realization of Ukrainian economic diplomacy. Uruguay recognized Ukraine on December 26, 1991, and on May 27, 1992, the Agreement (in the form of an exchange of notes) on the establishment of diplomatic relations between Ukraine and the Eastern Republic of 
Uruguay entered into force. The next contacts at the level of government of the countries took place on April 24-25, 2012, when Minister for Foreign Affairs of Ukraine K. Gryshchenko visited Montevideo. This was the first official visit of the head of the foreign policy department of Ukraine to Uruguay (EUAR. Political relations between Ukraine and Uruguay, 2018). Nowadays, in the history of bilateral relations, there is none official visits at the level of heads of state.

Agreement on the abolition of the visa regime for travel of citizens of Ukraine and Uruguay was signed as a result of meeting between Ministers of Foreign Affairs of Ukraine and Uruguay in 2018, within the framework of the 73rd session of General Assembly of United Nations. This is a confirmation of the implementation of such measure of economic diplomacy in the system of external interests of the state as tourism. Possibly, as a result of this, there was a revival of bilateral trade according to the State Statistics Service of Ukraine in January-October 2018, more than doubled in comparison with the same period in 2017. Ukrainian-Uruguay trade turnover amounted to \$11.7 million, of which imports of Uruguayan goods to Ukraine amounted to $\$ 11.2$ million $-95.7 \%$ of total commodity turnover. However, the balance of bilateral trade continues to be negative for Ukraine: $-\$$ 10.7 million (EUAR. Trade and economic cooperation between Ukraine and Uruguay, 2018).

Legal framework between Ukraine and Uruguay is not developed at good level. Only six documents have been signed. Geographical remoteness of countries as well as the lack of the necessary contractual and legal framework in this direction does not promote the development of economic relations. Cultural-humanitarian cooperation between Ukraine and Uruguay did not find development in the history of bilateral relations. Today, only the presence of sporadic contacts of a cultural nature and the activities of the Honorary Consul of Ukraine in Uruguay, Diego Guadalupe Brenni, can be considered as achievements in this field (EUAR. Cultural and humanitarian cooperation between Ukraine and Uruguay).

Ukrainian-Paraguayan relations haven't got special successes. Thus, diplomatic relations between the two states were established on February 26, 1993, but contacts between the two countries began to be settled only at the beginning of XXI century, because since 1997 the Ambassador of Ukraine to Argentina has served as Non-resident Ambassador to Paraguay. In February 2004, the Paraguayan party, for the first time after the establishment of diplomatic relations between the two states, appointed the head of the diplomatic mission of Paraguay in the Vatican Marcos Martínez Mendíta as Non-resident Ambassador to Ukraine.

The Honorary Consulate of Ukraine was opened on September 2002, in Frama, Paraguayan Department of Itapua, where ethnic Ukrainians live in a compact place (EUAR. Political relations between Ukraine and Paraguay, 2018).

The lack of development of political and cultural relations has influence on UkrainianParaguayan trade and economic relations. In January-October 2018, according to the data of the State Statistics Service of Ukraine, the negative tendencies of the reduction of bilateral trade volumes continued. It is worth pointed out that, in 10 months of 2018 bilateral trade turnover decreased by $22 \%$ compared to the same period in 2017 and amounted to \$ 97.2 thousand, including export - \$ 51.8 thousand, import - \$45.4 thousand. In 2018, the State Statistics Service of Ukraine did not record trade in services. The improvement of the current stage of relations in this area should be facilitated by the Second Joint Meeting of the Intergovernmental Ukrainian-Paraguay Commission on Trade and Economic Cooperation, which should take place in Kyiv (EUAR. Trade and economic cooperation between Ukraine and Uruguay, 2018). Thus, a revival of trade between Ukraine and Paraguay could be anticipated in 2019.

The contractual and legal basis of the Ukrainian-Paraguayan relations consist of 10 intergovernmental, intergovernmental, interagency, interregional and interinstitutional agreements, providing a minimum legislative framework for the development of bilateral cooperation in the political and economic spheres. The entry into force of the Treaty on Friendship and Cooperation between Ukraine and Paraguay took place on February 1, 2018, and on May 21, 2018, a parliamentary group on inter-parliamentary relations with Paraguay (6 deputies) was formed in the Verkhovna Rada of Ukraine. However, the Agreement on Trade and Economic Cooperation was signed only in 
February 2008 (EUAR. Legal basis between Ukraine and Paraguay).

Therefore, Ukrainian economic diplomacy with Paraguay can be characterized as a failure, because of the state of the trade balance in spite of the positive balance for Ukraine.

\subsection{The Embassy of Ukraine in Federative Republic of Brazil}

Ukrainian-Brazilian relations are one of the most interesting for our investigation, because Brazil is the largest country in Latin America. Rostislav Tronenko is Extraordinary and Plenipotentiary Ambassador of Ukraine to Brazil since 2010. First of all, we have admitted, that analyzing the dynamics of the development of political relations between Ukraine and Brazil basing on the information of the website of the Embassy of Ukraine, is not very convenient, because information posted on site indicates the development of relations since 2003. So, this web-site have not represented all information (Embassy of Ukraine in the Federative Republic of Brazil (EUFRB). Political relations between Ukraine and Brazil). A separate interesting aspect is the fact that after the Revolution of Dignity, in the winter of 2013-2014, Ukrainian-Brazil contacts at a high level of political dialogue renewed only in 2017. At the same time, the inter-parliamentary dialogue lasted all this time. The contractual and legal basis of the UkrainianBrazil relations is represented by more than 80 joint documents of various levels and directions (from memorandums to bilateral agreements). According to the web-site information, the last documents between Ukraine and Brazil were signed in 2014 (EUFRB. Legal basis between Ukraine and Brazil). It should be noted that the contractual basis on economic issue became larger, especially after the signing the Agreement between the Government of Ukraine and the Government of the Federal Republic of Brazil on trade and economic cooperation on September 11, 1996.

Brazil is one of the largest trading partners of Ukraine in Latin America. According to the State Statistics Service of Ukraine, in 2017, bilateral trade increased by 3\% to \$ 161 million, while exports of goods from Ukraine to Brazil dropped by $44 \%$ to $\$ 6$ million, imports of Brazilian goods to Ukraine increased by $7 \%$ to $\$ 155$ million. The negative balance for Ukraine was $\$ 148$ million (EUFRB. Trade and economic cooperation between Ukraine and Brazil). The website of the Embassy of Ukraine in Brazil contains the section "Trade and Economic Cooperation between Ukraine and Brazil" containing the tabs: Export Oriented Companies of Ukraine, Investment Opportunities in the Infrastructure Area in Ukraine, Review of Foreign Markets, Expansion of Exports of Ukrainian Products. At the same time, references to these sections are opened on the relevant structural subdivisions of Ukraine, the sites of which are not presented in Portuguese, which is an obstacle to deepening bilateral cooperation in economic field. Moreover, web-sites of The Embassy of Ukraine in Brazil, the General Consulate of Ukraine in Rio de Janeiro and the Consulate of Ukraine in Curitiba have the same information, but it logical that in different places must be held different events and some specific information for local citizens and Ukrainians. From the point of view of economic diplomacy, the exhibitions, which present the economic opportunities of Ukraine, its sphere of production, various goods, tourist opportunities of Ukraine and so on, would be important information for Brazilians.

At the same time, we have to paid attention that the work of the Ukrainian Embassy in Brazil is the most active, ramified and versatile (compared with the work of other embassies of Ukraine in the countries of LA). There is a lot of information about the features of the Brazilian market, radio programs, and interviews. For example, the radio program of the World Parliamentary Senate dedicated to Ukraine, which broadcasted on February 9, 2018. The program "Parliaments of the World" was devoted to the economy, culture and history of Ukraine, in particular the development of Ukrainian parliamentarism. Interviews with Ambassador of Ukraine to Brazil R. Tronenko and deputy of the Verkhovna Rada of Ukraine V. Romaniuk, president of the Ukrainian-Brazilian group of inter-parliamentary friendship were used in this program. The program was broadcasted simultaneously by 20 radio stations from different Brazilian stations, including 10 stations that creates the Radio Senado network (Embaixada da Ucrania no Brazil, 2018). It was a good instrument of Ukrainian digital diplomacy as well as economic diplomacy in creating attractive image of a country.

The web-site introduces the interview with Ambassador of Ukraine to the network of MERCOSUR 
on the occasion of 25 years of diplomatic relations between Ukraine and Brazil (Embaixada da Ucrania no Brazil, 2017). The article by Ambassador of Ukraine to Brazil R. Tronenko on trade and evolution of bilateral relations entitled "The Importance of the Brazilian Market and its Possibilities for Ukraine" (2016) can be regarded as a good instrument of deepen Ukrainian-Brazil economic relations (Embaixada da Ucrania no Brazil, 2016). R. Tronenko noted that Ukraine and Brazil have a lot of common features such as a constant change in the rules of the game and corruption. He also highlighted that Brazil experiencing economic and financial crisis today that affecting joint projects and commodity turnover. The ambassador provided a general analysis of the vision of economic situation in Brazil, explaining in this way the reasons for the decline in trade between Ukraine and Brazil. He noted that today Brazil looks somewhat unpredictable and difficult partner for the world community and gave an example as a proof of this statement. Brazilian side closed the project "Cyclone-4-Alcantara" (Ukraine have fulfilled already its part of the deal (readiness was more than $80 \%$ ) due to lack of funds and some political problems in Brazil. The Ambassador noticed that Brazilian market is rather complicated, because it is much protected (with many protectionist measures).

The ambassador identified such perspective areas of cooperation as: aircraft engineering, science and technology, higher education, agriculture, machine building, car building, infrastructure, energy saving technologies, pharmacology. With the change of government, Brazilian market also changed rules, which require knowledge of the Portuguese language. Brazil market has a lot of competition between European, Asian and North American companies.

We agree with ambassador's view about importance to know Portuguese language for business, but as have been noted above, the links on the embassy page connect users to Ukrainian sites in Ukrainian or English.

Ukrainian-Brazil economic cooperation has some negative trends nowadays. Brazil has implemented anti-dumping duties on Ukrainian steel, tires and pipes. They work today. Exports of fertilizers from Ukraine to Brazil and the import of Brazilian meat to Ukraine dropped sharply in 2014.

The Ukrainian community, which is concentrated mainly in the south of Brazil, has more than 1 million citizens. This fact has affected Brazil's recognition of bilateral relations between Brazil and Ukraine as the highest level of strategic partnership (EUFRB, 2018).

Plurinational State of Bolivia. Ukraine and Bolivia established diplomatic relations on February 8, 1992. Political contacts are almost absent. Ukrainian-Bolivian relations revived only at the beginning of the XXI century, after the Honorary Consulate of Ukraine began to act in La Paz in 1999. Deputy Minister for Foreign Affairs of Bolivia H. Humusi paid a visit to Ukraine on October 28, 2004. There are only two valid documents: Joint Communiqué on the establishment of diplomatic relations between Ukraine and the Multinational State of Bolivia, Protocol on the establishment of a consultation mechanism between the Ministry of Foreign Affairs of Ukraine and the Plurinational State of Bolivia (EUFRB. Political relations between Ukraine and Bolivia).

Due to the underdevelopment of political relations and the almost absent contractual base, the level of trade and economic cooperation is very low. According to the State Statistics Service of Ukraine, in 2017 (EUFRB. Trade and economic cooperation between Ukraine and Bolivia), trade between Ukraine and Bolivia increased by $69 \%$ compared to the same period in 2016 and amounted to $\$ 916$ thousand. At the same time, Ukrainian exports doubled and amounted to $\$ 77.6$ thousand, imports from Bolivia increased by $65 \%$ to $\$ 838.3$ thousand. Ukrainian exports mainly consisted of fertilizers $(61.3 \%)$ and optical and photographic equipment $(34.2 \%)$. The main products of Bolivian exports were inorganic chemistry products (74.4\%), edible fruits and nuts (17.5\%).

Co-operative Republic of Guyana. As with the previous country (Bolivia), relations between Ukraine and Guyana are only in the stage of becoming. Today we have a Joint Communique on the establishment of diplomatic relations (dated November 15, 2001). An agreement between the Government of Ukraine and the Government of the Republic of Guyana on trade and economic cooperation was signed on November 16,2005 . So far, the Ukrainian-Guyana relations are carried out mainly at the level of bilateral contacts between diplomatic representations of two countries, accredited in Brazil, as well as cooperation within the framework of international organizations 
(EUFRB. Political relations between Ukraine and Guyana).

In the economic sphere, according to the State Statistics Committee of Ukraine, in 2017, Ukraine exported Guyana's goods 9 times more than in the same period in 2016 to the amount of \$389.3 thousand. Ukrainian export consist of fats and oils were valued at \$337.4 thousand Imports from Guyana increased by $10 \%$ to $\$ 39.86$ million. The main type of Guyana's import to Ukraine was bauxite ( $\$ 39.84$ million). The total turnover was $\$ 40.25$ million, while the trade balance deficit $-\$$ 39.47 million (EUFRB. Trade and economic cooperation between Ukraine and Guyana).

Republic of Suriname. Diplomatic relations between Ukraine and Suriname were established on September 20, 2006, when the Joint Communiqué on establishment of diplomatic relations between Ukraine and the Republic of Suriname was signed. Ukrainian-Suriname relations are realized in the same way that the Ukrainian-Guyana, being just a little developed, not dynamic (EUFRB. Political relations between Ukraine and Surinam).

According to the State Statistics Service of Ukraine, in 2017, the bilateral trade with Suriname increased by almost 3 times and amounted to \$ 1.34 million. The main export items from Ukraine were fats and oils of animal and vegetable origin in the amount of $\$ 786.5$ thousand, which is $77 \%$ exceeded exports in January-September 2016, sugar and sugar confectionery products worth \$ 478.1 thousand (there were no supplies in 2016) and $\$ 67,000$ - nuclear reactors, boilers and machines. Suriname imports decreased by $62 \%$ and amounted to $\$ 2$ thousand. The main import goods are live animals worth $\$ 1$ thousand. The positive balance in trade was $\$ 1.33$ million.

\section{$4 \cdot 3$}

The Embassy of Ukraine in United Mexican States

United Mexican States. The relationship between Ukraine and Mexico was established on January 14, 1992. The Embassy of Ukraine in Mexico started its activity in March 1999, the official opening of which took place in November 2000 (Embassy of Ukraine in the United Mexican States (EUUMS). Political relations between Ukraine and Mexico). Ruslan Spirin has been the Extraordinary and Plenipotentiary Ambassador of Ukraine to Mexico since 2012.

Official web-site of the Embassy of Ukraine in Mexico in accordance with trade and economic cooperation between Ukraine and Mexico has specific points presented on the website: Evolution of trade and economic relations, Exhibitions and fairs in Mexico, Proposals of Ukrainian enterprises, Export and investment opportunities of the regions of Ukraine. This information is positive and attracts investors, but, for example, with regard to the schedule of the fair, it represents old information and applies to 2016 (EUUMS. Exhibitions and fairs in Mexico). As a result, the strategy of involving civil society under the influence of Ukrainian economic diplomacy does not work with all strength, as in almost all countries of the Latin America.

The page with proposals from Ukrainian enterprises is extremely rich in information and contributes to deepening bilateral relations. It is noted that on the page of the Council of Exporters and Investors of the Ministry of Foreign Affairs of Ukraine you can be acquainted with current commercial offers from Ukrainian companies representing the agrarian sector, machine building, heavy industry, etc (Embahada de Ucrania en los Estados Unidos Mexicanos (n.d.). Propuestas de Empresas Ucranianas). The proposal of cooperation with different Ukrainian regions: Lviv, Ternopil, Chernivtsi, Mykolaiv, Dnipropetrovsk, Ivano-Frankivsk, Zaporizhzhia is important to develop interregional cooperation (Embahada de Ucrania en los Estados Unidos Mexicanos. Las propuestas comerciales de las regiones de Ucrania).

Mexico occupies the second place, after Brazil, among the main trading partners of Ukraine in Latin America and the Caribbean region. According to the State Statistics Service of Ukraine, in 2017 the volume of trade in goods and services amounted to $\$ 267.836$ million, which is $13 \%$ more than in 2016. The positive trade balance of $\$ 7.874$ million was in 2017 (EUUMS. Trade and economic cooperation between Ukraine and Mexico).

The current stage of humanitarian cooperation contributes, in our opinion, to the development of relations between countries, including trade (EUUMS. Cultural and humanitarian cooperation 
between Ukraine and Mexico). The legal framework consists of 25 documents, at the same time, we note that the possibilities of economic diplomacy are not used in complex. Relations between the countries are developing not dynamically and do not cover all possible areas of cooperation, also marked by scandalous events. Two Mexican citizens married to Ukrainian women accused the Mexican Embassy of requiring money for the needs of the Ukrainian Army from Mexicans to receive a visa (Scandal with the Ukrainian embassy: Mexicans talked about unofficial "fees" for visas, 2019). Such facts have negative influence on Ukrainian image abroad.

Republic of Costa Rica. Diplomatic relations were established on June 9, 1992. Contacts at the highest level took place only during the multilateral summits, in particular, during the Summit of Heads of State of the Association of the Caribbean States (Santo Domingo, Dominican Republic) in June 1999 or during sessions UN GA (№54, №65, №69). Current documents: Protocol on the establishment of diplomatic relations (June 9, 1992) and the Memorandum of Understanding on the launch of the mechanism of political consultations between Ministries of foreign affairs of two countries (September 24, 2010) (EUUMS. Political relations between Ukraine and Costa Rica).

The volumes of bilateral trade in goods between the two countries increased by $72 \%$ in 2018 , which amounted to $\$ 87.489$ million. Export volumes of Ukrainian goods increased by $114 \%$ to $\$$ 50.302 million, while imports of goods from Costa Rica rose by $35 \%$ and amounted to $\$ 37.187$ million. The main export goods are ferrous metals - $87.1 \%$, goods of import - edible fruits and nuts - $93.7 \%$ (EUUMS. Trade and economic cooperation between Ukraine and Costa Rica]).

Republic of Guatemala. Diplomatic relations were established on January 12, 1993. The contractual and legal base of the foreign relations consist of five documents. An official visit of the Minister for Foreign Affairs of Guatemala, Edgar Gutierrez to Ukraine, was held in October 2003 and other meetings took place during the sessions of the United Nations.

According to the State Statistics Service of Ukraine, in 2018, exports of Ukrainian goods to Guatemala increased by $335 \%$ to $\$ 1.858$ million, while imports from Guatemala dropped by $26 \%$ to $\$$ 43.934 million. The structure of Ukrainian export products to Guatemala consisted of nuclear reactors $(72.6 \%)$. The main import items were ore, slag and ash (88.0\%), tobacco (6.7\%) (EUUMS. Trade and economic cooperation between Ukraine and Guatemala]).

Republic of Panama. The establishment of diplomatic relations between Ukraine and Panama was held on May 21, 1993, at the Embassy of Ukraine in Mexico as Non-resident Embassy of Panama. The Embassy of Panama in the Hellenic Republic serves as Non-resident Embassy of Panama in Ukraine. The Honorary Consulate of Panama works in Kyiv. Since the establishment of diplomatic relations, visits at the level of heads of state/government have not taken place. Official visit of Minister for Foreign Affairs of Ukraine L. Kozhara to Panama was held on August 21-23, 2013. The number of valid documents is 11 . Most of them apply to visa-free travel of citizens, mutual protection of investments and legal assistance in criminal matters. The peculiarity of economic relations between Ukraine and Panama is the mutual trade in services, which is almost an exception in comparison with other countries of the Latin America (EUUMS. Political relations between Ukraine and Panama).

As a result of 10 months of 2018, the volume of trade in goods between Ukraine and Panama decreased by $57 \%$ compared to the same period in 2017 and amounted to $\$ 8.824$ million with a positive balance of $\$ 1.236$ million for Ukraine. Exports of Ukrainian goods to Panama decreased by $73,8 \%$ and amounted to $\$ 5,030$ million, imports from Panama increased by $279 \%$ to \$3,794 million. The main items of Ukrainian export to Panama in 2018 were vessels (42.6\%), optical devices and apparatuses $(22,5 \%)$, rubber and caoutchouc (12.3\%). The main products of import from Panama were edible fruits and nuts $(87.9 \%)$, goods purchased in ports $(6.1 \%)$, chemical products $(1.7 \%)$, and textiles (1.4\%). Investments into the Ukrainian economy amounted to \$330.9 million and were primarily directed to the real estate business (4.6\%) and professional and scientific activities (3.5\%) in 2018 (EUUMS. Trade and economic cooperation between Ukraine and Panama).

Belize. Recognition of Ukraine and establishment of diplomatic relations was on October 1, 1999. Contacts are not available. Number of current documents is only 1 - Joint communiqué on the establishment of diplomatic relations on October 1, 1999. 
The volume of trade in goods in 2018 decreased by $56 \%$ compared to the same period in 2017 and amounted to \$3,011 million for the positive balance for Ukraine in the amount of \$2.971 million.

The basis of Ukrainian export were vessels (93.6\%), ferrous metals $(2.7 \%)$, oil and petroleum products (0.8\%); import - tannic extracts (75.0\%), optical instruments and apparatuses (12, 5\%), nuclear reactors $(7.4 \%)$. The volume of trade in services between the two countries on the results of the III quarter of 2018 amounted to \$ 13.159 million. Exports of services from Ukraine amounted to \$ 12.999 million, imports from Belize - decreased by $91.5 \%$ and amounted to $\$ 160$ thousand. The positive balance in favor of Ukraine was \$ 12.839 million. Transportation services (46.7\%), telecommunication, computer and information services (14.7\%), business services $(8.4 \%)$, and travel services (7.3\%) are dominated in Ukrainian exports. Financial services (62.0\%), telecommunication, computer and information services $(3.9 \%)$ were the basis for import.

Belize occupies the first place among Latin American and Caribbean countries (13th among all countries of the world) in investments attracted into the Ukrainian economy. According to the results of 2018, they amounted to $\$ 518.3$ million and were directed to the sphere of food products, beverages and tobacco products $(36 \%)$, real estate operations $(29.6 \%)$, industry (11\%), wholesale and retail trade $(8 \%)$, construction (5\%), professional and scientific activity (4.7\%), etc (EUUMS. Trade and economic cooperation between Ukraine and Belize]).

\section{4}

\section{The Embassy of Ukraine in Republic of Cuba}

Republic of Cuba. The Ukrainian-Cuban relations were established on March 12, 1992. The Republic of Cuba was one of the first countries of Latin America recognized the independence of Ukraine. The Embassy of Ukraine in Cuba was opened in Havana in 1992. Mykhailo Khomenko is Extraordinary and Plenipotentiary Ambassador of Ukraine to Cuba. The political relations are sufficiently branched. The Intergovernmental Ukrainian-Cuban Commission for Trade-Economic, Scientific and Technical Cooperation (the last X meeting was held in November 2010 in Havana) was established and functioning (Embassy of Ukraine in the Republic of Cuba (EURC). Political relations between Ukraine and Cuba).

Trade and economic relations between Ukraine and Cuba at the embassy's web-site are not adequately covered, which is confirmed by outdated information for 2015 (EURC. Trade and economic cooperation between Ukraine and Cuba). In particular, the questionnaires of 46 exportoriented enterprises of Ukraine from different regions in English were placed.

Among the main interests of Ukraine in bilateral relations with Cuba in the economic sphere and the main areas of cooperation are trade and economic cooperation, cooperation in aviation, chemical, machine-building (trucks, tractors), medical, pharmacological, mining, energy and rural sectors, agriculture.

Among the economic activities between Ukraine and Cuba should be mentioned the 33rd International Havana Fair (FIHAV 2015), which lasted from 2 to 7 November 2015 at the EXPOCUBA International Exhibition Complex. The Scientific and Production Company "Spectr", which offered products and services of more than 30 Ukrainian enterprises and organizations for Cuban market, represented Ukraine at the exhibition. Therefore, during the exhibition, members of the Ukrainian delegation introduced a presentation of metallurgical projects for the leadership of the Ministry of Industry of Cuba. Among perspective Ukrainian-Cuban projects should be highlighted such as negotiations with the Cuban state-owned company EMTA on the contract for manufacturing and supplying tower cranes to Cuba; negotiations for participation in the tender for the modernization of the rolling mill of the metallurgical plant in Las Tunas province; negotiations with the company "Cubana de Aviación" and "Aviaimport" on the organization of technical support of Ukrainian aircraft An-158; negotiations with representatives of the Cuban hotel business on the participation of Ukrainian companies in modernizing the existing and equipping new hotels in Cuba.

The volume of trade in goods between Ukraine and Cuba in 2015 amounted to $\$ 37.56$ million, which is $56.5 \%$ less than in 2014, while exports of Ukrainian goods to Cuba declined by $57.1 \%$ to $\$ 36$, $38 \mathrm{mln}$. Imports from Cuba declined by $26.2 \%$ and amounted to $\$ 1.18 \mathrm{mln}$. The surplus for Ukraine 
was $\$ 35.2 \mathrm{mln}$. Ukrainian exports to Cuba consist of aircraft (69.3\%), nuclear reactors, boilers, machinery (10.9\%), and land transport vehicles except rail (6.3\%). Imports to Ukraine introduced by nuclear reactors, boilers, cars $(48.2 \%)$, various drinks and vinegar (25.5\%), optical and photographic instruments and apparatuses (18.3\%).

The volume of trade in services is very low. In 2015, they amounted to $\$ 1.1$ million, an increase of 15.7\% compared to 2014. At the same time, exports of Ukrainian services to Cuba increased by $38.2 \%$ to $\$ 437.2$ thousand, while imports from Cuba increased by $4 \%$ and amounted to $\$ 666.5$ thousand. Negative balance in trade for Ukraine was \$229.4 thousand.

According to the State Statistics Service of Ukraine, the volume of foreign direct investment in the Ukrainian economy from Cuba amounted to \$2.1 million in 2014 (at the beginning of $2013-\$ 421.5$ thousand). The largest amount volumes of foreign direct investments came to the healthcare and pharmaceuticals sectors. Ukrainian investment in the Cuban economy was not registered.

Thus, according to the State Statistics Service of Ukraine, the volume of foreign trade in goods and services between Ukraine and Cuba in 2015 amounted to \$ 38.66 million. The positive balance for Ukraine was \$ 34.97 million. From the 59 valid documents of bilateral cooperation one third is devoted to the economic direction - 21, other documents implemented political direction, scientific cooperation, humanitarian and interregional cooperation, consular legal issues (EURC. Trade and economic cooperation between Ukraine and Cuba).

Bolivarian Republic of Venezuela. Information about Ukraine-Venezuela relations is not available on the web-site of the Embassy of Ukraine in Cuba (namely, the Ukrainian embassy in Cuba represents the interests of Ukraine in Venezuela and Dominican Republic). On the website of the State Statistics Committee of Ukraine, we find that trade between Ukraine and Venezuela is \$ 19 million.640 thousand and Ukraine has positive balance of \$ 19 million 481 thousand (State Statistics Service of Ukraine, 2018).

Dominican Republic. Political relations between Ukraine and the Dominican Republic are not very developed. Official information is almost non-existent, besides, some projects are only under the stage of developing. For instance, an agreement between the Ministry of Education and Science and the State Secretariat of Education of the Dominican Republic on cooperation in the field of education and science, Agreement between the Ministry of Defense of Ukraine and the State Secretariat of the Armed Forces of the Dominican Republic on military cooperation, Agreement on promotion and protection of investments, Agreement between Ukraine and the Dominican Republic on Legal Assistance and Legal Relations in Civil and Criminal Matters, Agreement on Avoidance of Double Taxation. Official visit to Ukraine by President I. Mejia was in June 2002. The Minister for Foreign Affairs of Ukraine A. Zlenko made the official visit to the Dominican Republic at the invitation of the President of the Dominican Republic, Raphael I. Mejia in September 2002 (EURC. Legal basis between Ukraine and Dominican Republic).

According to the State Statistics Service of Ukraine, trade with Dominican Republic is \$ 3.812 mln with a positive balance for Ukraine of \$10,000.

\subsection{The Embassy of Ukraine in Republic of Peru}

Republic of Peru. The Embassy of Ukraine in Peru is located in Lima, and the Ambassador is Igor Tumasov. This embassy also represents Ukrainian interests in Ecuador and Colombia. The section of website devoted to Ukrainian-Colombia relations is not full of material and only provides Recommendations on the rules for Ukrainian citizens traveling to the Republic of Colombia. Ecuador, is the second largest import partner for Ukraine in South America after Brazil.

The state of trade and economic cooperation between Ukraine and Peru is represented on the embassy's website with outdated information for 2015-2016 (Embassy of Ukraine in the Republic of Peru). It is positive moment that the list of export-oriented enterprises of Ukraine and the calendar of the international exhibition-fairs events in Peru for 2015 and 2016 are exist at website. But again, nowadays we have 2019 and mentioned information is outdated. 


\section{Empirical Results and Some Recommendations}

The information obtained from the websites of the diplomatic missions of Ukraine in Latin America region and the State Statistics Service of Ukraine were systematized in the form of tables. Thus, Table 1. illustrates the ratio of population, GDP volume, presence of embassy, the number of Ukrainian diaspora to total trade (in relation to the countries of the Latin America which have embassies in Ukraine, Ukraine has its embassies in these countries or in which Ukraine interests is represented by the Nonresident ambassador of Ukraine). Actually, the table illustrates the opportunities and some positive moments that Ukraine does not use in economic relations with Latin American countries. Table 2. and Table 3. are introduced in order to better analyze the lost opportunities of Ukraine as well.

Table 1:

\begin{tabular}{|c|c|c|c|c|c|c|}
\hline $\begin{array}{l}\text { Name of } \\
\text { country }\end{array}$ & $\begin{array}{l}\text { Amount of } \\
\text { population }\end{array}$ & $\begin{array}{c}\text { GDP (\$ } \\
\text { million) }\end{array}$ & $\begin{array}{l}\text { Presence of embassy / consulate of } \\
\text { Ukraine }\end{array}$ & $\begin{array}{c}\text { Number of Ukrainian } \\
\text { Diaspora (person) }\end{array}$ & $\begin{array}{c}\text { Total } \\
\text { volume of } \\
\text { trade } \\
\end{array}$ & $\begin{array}{c}\text { The } \\
\text { balance for } \\
\text { Ukraine }\end{array}$ \\
\hline Ukraine & 42216800 & 2983882 & $\begin{array}{l}\text { Such LA countries have embassies in Ukraine } \\
\text { - Argentina, Brazil, Cuba, Chile, Mexico, and } \\
\text { representation of the military attache of the } \\
\text { embassy of Peru }\end{array}$ & 824350 & $\begin{array}{l}\text { About } \$ 1 \\
\text { billion. }\end{array}$ & $\begin{array}{l}-\$ 308 \\
\text { million }\end{array}$ \\
\hline Argentina & 44938712 & 518092 & $\begin{array}{l}\text { Embassy of Ukraine in Argentina (Buenos- } \\
\text { Aires)c }\end{array}$ & 300000 & $\begin{array}{l}\$ 72.6 \\
\text { million }\end{array}$ & $\begin{array}{l}-\$ 53,32 \\
\text { million }\end{array}$ \\
\hline Paraguay & 7112594 & 41604 & Embassy of Ukraine in Argentina & 12000 & $\begin{array}{c}\$ 97.2 \\
\text { thousand }\end{array}$ & $\begin{array}{c}\$ 6,4 \\
\text { thousand }\end{array}$ \\
\hline Uruguay & 3415866 & 60180 & Embassy of Ukraine in Argentina & 2000 & $\begin{array}{l}\$ 11,7 \\
\text { million }\end{array}$ & $\begin{array}{l}-\$ 10,7 \\
\text { million }\end{array}$ \\
\hline Chile & 18707416 & 298172 & Embassy of Ukraine in Argentina & 1150 & $\$ 42$ million & $-\$ 34$ million \\
\hline Brazil & 209000000 & 1868184 & Embassy of Ukraine in Brazil (São Paulo) & 500000 & $\begin{array}{c}\$ 161 \\
\text { million }\end{array}$ & $\begin{array}{c}-\$ 148 \\
\text { million }\end{array}$ \\
\hline Bolivia & 17410651 & 34080 & Embassy of Ukraine in Brazil & $\begin{array}{c}\text { (no information } \\
\text { available) }\end{array}$ & $\begin{array}{c}\$ 916 \\
\text { thousand }\end{array}$ & $\begin{array}{c}-\$ 760,7 \\
\text { thousand }\end{array}$ \\
\hline Gayana & 801623 & 3636 & Embassy of Ukraine in Brazil & $\begin{array}{c}\text { (no information } \\
\text { available) }\end{array}$ & $\begin{array}{l}\$ 40,25 \\
\text { million }\end{array}$ & $\begin{array}{l}-\$ 39,47 \\
\text { million } \\
\end{array}$ \\
\hline Suriname & 547610 & 3427 & Embassy of Ukraine in Brazil & $\begin{array}{c}\text { (no information } \\
\text { available) }\end{array}$ & $\begin{array}{c}\$ 1,34 \\
\text { million. }\end{array}$ & $\$ 1,33$ million \\
\hline Cuba & 11658566 & 96851 & Embassy of Ukraine in Cuba (Havana) & to 400 persons & $\begin{array}{l}\$ 38,66 \\
\text { million }\end{array}$ & $\begin{array}{c}\$ 34,97 \\
\text { million } \\
\end{array}$ \\
\hline Venezuela & 32349000 & 209200 & Embassy of Ukraine in Cuba & $\begin{array}{c}\text { no information } \\
\text { available }\end{array}$ & $\begin{array}{l}\$ 19,640 \\
\text { million }\end{array}$ & $\begin{array}{l}\$ 19,481 \\
\text { million } \\
\end{array}$ \\
\hline $\begin{array}{l}\text { Dominican } \\
\text { Republic } \\
\end{array}$ & 10648613 & 80940 & Embassy of Ukraine in Cuba & $\begin{array}{c}\text { no information } \\
\text { available }\end{array}$ & $\begin{array}{c}\$ 3,812 \\
\text { million }\end{array}$ & $\begin{array}{c}\text { \$10 } \\
\text { thousand }\end{array}$ \\
\hline Mexico & 133140936 & 1223359 & Embassy of Ukraine in Mexico (Mexico) & 220 & $\begin{array}{l}\$ 267,836 \\
\text { million }\end{array}$ & $\begin{array}{l}-\$ 7,874 \\
\text { million }\end{array}$ \\
\hline Costa Rica & 4953199 & 59006 & Embassy of Ukraine in Mexico & $\begin{array}{c}\text { no information } \\
\text { available }\end{array}$ & $\begin{array}{l}\$ 87,489 \\
\text { million }\end{array}$ & $\begin{array}{c}\$ 13,115 \\
\text { million }\end{array}$ \\
\hline Guatemala & 25176133 & 75620 & Embassy of Ukraine in Mexico & $\begin{array}{c}\text { no information } \\
\text { available }\end{array}$ & $\begin{array}{l}\$ 45,792 \\
\text { million }\end{array}$ & $\begin{array}{c}-\$ 42,076 \\
\text { million } \\
\end{array}$ \\
\hline Panama & 3764166 & 65206 & Embassy of Ukraine in Mexico & $\begin{array}{c}\text { no information } \\
\text { available }\end{array}$ & $\begin{array}{l}\$ 8,824 \\
\text { million } \\
\end{array}$ & $\begin{array}{c}\$ 1,236 \\
\text { million } \\
\end{array}$ \\
\hline Belize & 387879 & 1862 & Embassy of Ukraine in Mexico & $\begin{array}{c}\text { no information } \\
\text { available }\end{array}$ & $\begin{array}{c}\text { \$3,o11 } \\
\text { million }\end{array}$ & $\begin{array}{c}\$ 2,971 \\
\text { million }\end{array}$ \\
\hline Peru & 32162184 & 225203 & Embassy of Ukraine in Peru (Lima) & To 280 & $\$ 18$ million & $\$ 3,2$ million \\
\hline Colombia & 50296000 & 333114 & Embassy of Ukraine in Peru & To 230 & $\begin{array}{l}\$ 38,115 \\
\text { million }\end{array}$ & $\begin{array}{l}\$ 14,292 \\
\text { million }\end{array}$ \\
\hline Ecuador & 15976000 & 107511 & Embassy of Ukraine in Peru & To $35^{\circ}$ & $\begin{array}{l}\$ 62,6 \\
\text { million }\end{array}$ & $\begin{array}{l}-\$ 62,5 \\
\text { million }\end{array}$ \\
\hline
\end{tabular}

Source: it is the authors' analysis the dates from official web-sites of Ukrainian embassies in LA countries, Site of State Statistics Service of Ukraine (Sajt derzhavnoyi sluzhby'staty'sty' ky' Ukrayiny'. ukrstat.gov.ua. Retriever from: http://www.ukrstat.gov.ua) and Kolyada, O.V., \& Rajcheva, A.A. (2018). 
Table No 3. and Table No 4. represent the process of development of economic relations between Ukraine and all regions of the world since 2010. Significant is the fact that America (North and South, with the Caribbean) occupy the penultimate position as a partner for Ukraine. There is a difference in the figures in trade in goods and services. Therefore, in the trade in services, we observe the fact that Ukraine sells more goods to African countries than America, but imports more from America, not from Africa. The second conclusion is that the Revolution of Dignity has significantly influenced trade relations. So, in particular, with regard to the countries of America, Ukraine has become less to sell and buy more after 2014. The third table shows that America is not occupies a penultimate position in trade in services, but stays in a position above. At the same time, figures about America are united, so we cannot see which America (the North or the South) is in the position of a more reliable partner of Ukraine in the economic sphere. In general, the analysis of trade volumes from 2010 shows a steady growth, with a fall after 2014.

Table 2: Dynamics of the geographical structure of foreign trade in goods of Ukraine (2010-2017)

\begin{tabular}{|c|c|c|c|c|c|c|c|c|c|}
\hline & Total $^{1}$ & $\begin{array}{c}\text { Post-Soviet } \\
\text { countries }\end{array}$ & Other countries & Europe & $\begin{array}{c}\text { European Union } \\
\text { countries }(28)\end{array}$ & Asia & Africa & America & $\begin{array}{c}\text { Australia and } \\
\text { Oceania }\end{array}$ \\
\hline \multicolumn{10}{|c|}{ Export (\$ million) } \\
\hline \begin{tabular}{|l|}
2010 \\
\end{tabular} & 51405,2 & 18740,6 & 32664,6 & 13829,6 & 13085,3 & 13715,4 & 3018,7 & 2000,0 & 28,4 \\
\hline \begin{tabular}{|l|}
2011 \\
\end{tabular} & 68394,2 & 26177,0 & 42217,2 & 18442,4 & 18021,5 & 17737,8 & 3344,2 & 2552,3 & 29,8 \\
\hline 2012 & 68830,4 & 25318,6 & 43511,8 & 17424,0 & 17123,7 & 17681,1 & 5638,2 & 2607,7 & 50,9 \\
\hline 2013 & 63320,7 & 22077,3 & 41243,4 & 17064,2 & 16758,6 & 16813,0 & 5094,7 & 2163,6 & 40,1 \\
\hline $2014^{2}$ & 53901,7 & 14882,3 & 39019,4 & \begin{tabular}{|l|}
17122,1 \\
\end{tabular} & 17002,9 & 15350,9 & 5098,2 & 1372,2 & 23,5 \\
\hline $2015^{2}$ & 38127,1 & 7806,1 & 30321,0 & 13248,3 & 13015,2 & 12378,9 & 3803,3 & 785,6 & 13,6 \\
\hline $2016^{2}$ & 36361,7 & 6031,5 & 30330,2 & 13790,1 & 13496,3 & 11796,3 & 3865,1 & 735,2 & 18,3 \\
\hline $2017^{2}$ & 43264,7 & 6916,4 & 36348,3 & 17901,9 & 17533,4 & 12967,3 & 4047,7 & 1207,9 & 71,9 \\
\hline \multicolumn{10}{|c|}{ Import (\$ million) } \\
\hline 2010 & 60742,2 & 26697,4 & 34044,8 & 20004,5 & 19151,4 & 10023,3 & 874,4 & 2879,4 & 261,4 \\
\hline 2011 & 82608,2 & 37212,4 & 45395,8 & \begin{tabular}{|l|}
27065,9 \\
\end{tabular} & 25805,8 & 13279,9 & 940,6 & 3913,9 & 194,0 \\
\hline \begin{tabular}{|l|}
2012 \\
\end{tabular} & \begin{tabular}{|l|}
84717,6 \\
\end{tabular} & 34497,2 & 50220,4 & \begin{tabular}{|l|}
27569,6 \\
\end{tabular} & 26237,2 & 17140,5 & 851,3 & 4446,7 & 195,7 \\
\hline 2013 & 76986,8 & 27941,6 & 49045,2 & 28566,2 & 27046,5 & 15237,3 & 749,8 & 4339,9 & 93,7 \\
\hline $2014^{2}$ & 54428,7 & 17276,9 & 37151,8 & 22383,0 & 21069,1 & 10848,3 & 679,9 & 3021,5 & 182,2 \\
\hline $2015^{2}$ & \begin{tabular}{|l|}
37516,4 \\
\end{tabular} & 10485,5 & 27030,9 & \begin{tabular}{|l|}
16665,3 \\
\end{tabular} & 15330,2 & 7235,8 & 601,7 & 2336,6 & 169,6 \\
\hline $2016^{2}$ & 39249,8 & 8565,4 & 30684,4 & 18470,2 & 17140,8 & 8920,5 & 553,9 & 2594,8 & 120,6 \\
\hline $2017^{2}$ & 49607,2 & 11477,9 & 38129,3 & 22922,4 & 20799,4 & 10679,4 & 719,0 & 3615,6 & 151,4 \\
\hline
\end{tabular}

${ }^{1}$ Taking into account the unallocated volumes of goods.

${ }^{2}$ Excluding the temporarily occupied territory of the Autonomous Republic of Crimea, Sevastopol and parts of the temporarily occupied territories in the Donetsk and Luhansk region.

Source: it is the authors' analysis the dates from Site of State Statistics Service of Ukraine (ukrstat.gov.ua. Retriever from: http://www.ukrstat.gov.ua).

Table 3: Dynamics of the geographical structure of foreign trade in services of Ukraine (2010-2017)

\begin{tabular}{|l|c|c|c|c|c|c|c|c|c|c|c|c|}
\hline & Total $^{1}$ & $\begin{array}{c}\text { Post-Soviet } \\
\text { countries }\end{array}$ & $\begin{array}{c}\text { Other } \\
\text { countries }\end{array}$ & Europe & $\begin{array}{c}\text { European Union } \\
\text { countries (28) }\end{array}$ & Asia & Africa & America & $\begin{array}{c}\text { Australia and } \\
\text { Oceania }\end{array}$ & $\begin{array}{c}\text { Otrer } \\
\text { countries }\end{array}$ \\
\hline \multicolumn{8}{|c|}{ Export } \\
\hline $\mathbf{2 0 1 0}$ & $\mathbf{1 1 9 3 6 , 3}$ & 5442,4 & 5939,0 & 3245,7 & 3123,1 & 1013,3 & 136,4 & 1156,7 & 37,2 & 349,6 \\
\hline $\mathbf{2 0 1 1}$ & $\mathbf{1 4 1 8 0 , 3}$ & 6041,1 & 7306,6 & 4037,8 & 3532,9 & 1108,4 & 154,9 & 1400,0 & 133,8 & 471,8 \\
\hline $\mathbf{2 0 1 2}$ & $\mathbf{1 4 0 9 6 , 2}$ & 5811,1 & 7304,9 & 3945,1 & 3750,2 & 1255,6 & 165,5 & 1427,7 & 230,6 & 280,3 \\
\hline $\mathbf{2 0 1 3}$ & $\mathbf{1 4 2 3 3 , 2}$ & 5814,9 & 8418,3 & 4883,7 & 4195,7 & 1427,0 & 153,0 & 1581,9 & 78,6 & 294,0 \\
\hline $\mathbf{2 0 1 4}^{*}$ & $\mathbf{1 1 5 2 0 , 8}$ & 4034,3 & 7486,5 & 4431,0 & 3991,6 & 1350,7 & 131,3 & 1242,8 & 71,5 & 258,9 \\
\hline $\mathbf{2 0 1 5}^{*}$ & $\mathbf{9 7 3 6 , 6}$ & 3544,8 & 6191,8 & 3521,4 & 2927,9 & 1120,3 & 145,1 & 1134,7 & 91,0 & 179,3 \\
\hline $\mathbf{2 0 1 6}^{*}$ & $\mathbf{9 8 6 8 , 0}$ & 3727,9 & 6140,1 & 3499,0 & 3004,9 & 1154,5 & 125,1 & 1132,9 & 37,8 & 190,8 \\
\hline $\mathbf{2 0 1 7}^{*}$ & $\mathbf{1 0 7 1 4 , 3}$ & 3763,9 & 6950,4 & 4019,5 & 3452,7 & 1301,9 & 149,3 & 1184,8 & 31,1 & 263,8 \\
\hline
\end{tabular}




\begin{tabular}{|c|c|c|c|c|c|c|c|c|c|c|}
\hline & Total $^{1}$ & $\begin{array}{l}\text { Post-Soviet } \\
\text { countries }\end{array}$ & $\begin{array}{c}\text { Other } \\
\text { countries }\end{array}$ & Europe & $\begin{array}{c}\text { European Union } \\
\text { countries }(28)\end{array}$ & Asia & Africa & America & $\begin{array}{c}\text { Australia and } \\
\text { Oceania }\end{array}$ & $\begin{array}{c}\text { Otrer } \\
\text { countries }\end{array}$ \\
\hline \multicolumn{11}{|c|}{ Import } \\
\hline 2010 & 5467,2 & 939,8 & 4507,9 & 2420,9 & 3029,4 & 1223,0 & 45,0 & 571,0 & 8,0 & 240,0 \\
\hline $2010^{*}$ & 5421,6 & 933,6 & 4468,5 & 2414,8 & 3000,3 & 1197,5 & 44,8 & 563,3 & 8,0 & 240,0 \\
\hline $2011^{*}$ & 6214,2 & 1166,3 & 5025,6 & 2804,2 & 3372,1 & 1377,1 & 36,4 & 570,3 & 10,2 & 227,3 \\
\hline $2012^{*}$ & 6650,1 & 1238,2 & 5401,0 & 3038,8 & 3641,2 & 1515,7 & 37,5 & 505,1 & 6,7 & 297,2 \\
\hline $2013^{*}$ & 7523,0 & 1466,5 & 6056,5 & 3531,2 & 4212,0 & 1585,1 & 35,1 & 580,4 & 3,9 & 320,9 \\
\hline $2014^{*}$ & 6373,1 & 1204,0 & 5169,1 & 3002,6 & 3148,8 & 920,8 & 44,3 & 694,8 & 3,6 & 503,1 \\
\hline $2015^{*}$ & 5523,0 & 839,6 & 4683,4 & 2749,1 & 2750,1 & 850,9 & 39,4 & 609,7 & 1,6 & 432,7 \\
\hline $2016^{*}$ & 5326,5 & 672,6 & 4653,9 & 2400,7 & 2421,6 & 888,8 & 40,7 & 773,4 & 1,3 & 549,0 \\
\hline $2017^{*}$ & 5476,1 & 650,4 & 4825,7 & $255^{8,6}$ & 2532,5 & 1086,3 & 80,8 & 724,9 & 1,7 & 373,4 \\
\hline
\end{tabular}

* Information from 2013 is given without taking into account the temporarily occupied territory of the Autonomous Republic of Crimea and the city of Sevastopol. Information for 2014-2016 - without taking into account the temporarily occupied territory of the Autonomous Republic of Crimea, the city of Sevastopol and parts of the zone of the anti-terrorist operation. For 2017 - without taking into account the temporarily occupied territory of the Autonomous Republic of Crimea, the city of Sevastopol and parts of the temporarily occupied territories in the Donetsk and Luhansk regions.

Source: it is the authors' analysis the dates from Site of State Statistics Service of Ukraine (ukrstat.gov.ua. Retriever from: http://www.ukrstat.gov.ua).

Table No 4. shows that LA countries, in which Ukraine has not opened its embassies and there is no other representation, have low trade volumes with Ukraine. Of course, these countries are not too significant in their capabilities, but on the other hand, with the industrial development of Ukraine, we have something to offer to small countries that do not have sufficient resources.

Table 4: Export-import of goods of Ukraine with countries of LA region, in which Ukraine does not have its own embassies in 2016

\begin{tabular}{|l|c|c|c|c|c|}
\hline \multirow{2}{*}{} & \multicolumn{2}{|c|}{ Export (\$ thousand) } & \multicolumn{3}{c|}{ Import (\$ thousand) } \\
\cline { 2 - 6 } & destination country & trading country & country of origin & country of departure & trading country \\
\hline Haiti & 82,2 & - & 18,0 & - & - \\
\hline Honduras & 30,2 & 28,8 & 1408,3 & 899,6 & - \\
\hline Dominica & 121,2 & 18030,1 & 20,7 & 183,2 & 1402,1 \\
\hline Nicaragua & 29,1 & 29,1 & 622,9 & 215,2 & 12,9 \\
\hline Puerto Rico & 945,6 & 874,7 & 3978,5 & 23,5 & 23,5 \\
\hline El Salvador & 7,8 & - & 305,9 & 118,7 & 0,9 \\
\hline
\end{tabular}

Source: it is the authors' analysis the dates from Site of State Statistics Service of Ukraine (ukrstat.gov.ua. Retriever from: http://www.ukrstat.gov.ua)

Table No 5. presents the most interesting results and shows that the largest volumes of trade in services occur precisely with those countries in which Ukraine is not represented by embassies and has low volumes of trade in goods. Nevertheless, this is a global trend, as in most cases, small inland areas are offshore areas and invest heavily (usually it is often impossible to pinpoint the exact investor) or are tourism centers, and therefore provide or buy (for example, transport) services. Accordingly, our recommendations for this item will be the next: Ukraine should open embassies in these countries and provide in them economic departments with the purpose to deepening economic relations and realization economic diplomacy as well. 
Table 5: Quarterly volumes of foreign trade in services with the countries of Latin America region in 2017

\begin{tabular}{|c|c|c|c|c|c|c|c|c|c|c|}
\hline & \multicolumn{5}{|c|}{ Export } & \multicolumn{5}{|c|}{ Import } \\
\hline & 2017 & I Quarter & II Quarter & III Quarter & IV Quarter & 2017 & I Quarter & II Quarter & III Quarter & IV Quarter \\
\hline Argentina & 554,6 & 114,5 & 79,2 & 187,1 & 173,8 & \begin{tabular}{|l|}
880,7 \\
\end{tabular} & 121,4 & 280,2 & 209,3 & 269,9 \\
\hline Belize & 22448,7 & 3001,1 & 5542,3 & 5064,1 & 8841,3 & 1901,6 & 1000,5 & 779,3 & 79,6 & 42,2 \\
\hline Gayana & 114,4 & 38,6 & 33,5 & 23,9 & 18,5 & - & - & - & - & - \\
\hline Guatemala & 95,8 & 4,0 & 41,4 & 0,4 & 50,1 & 5,5 & 0,0 & 0,1 & 5,4 & 0,1 \\
\hline Guinea & 549,2 & 160,3 & 48,1 & 272,3 & 68,5 & 36,1 & 0,0 & 0,0 & 31,5 & 4,6 \\
\hline Honduras & 210,5 & 164,1 & 19,0 & 3,9 & 23,6 & 2,4 & 1,1 & 0,0 & 0,0 & 1,3 \\
\hline Dominica & 1705,3 & 503,7 & 563,2 & 374,6 & 263,8 & 51,4 & 32,5 & 2,5 & - & 16,5 \\
\hline Dominican Republic & 2260,5 & 414,3 & 567,6 & 520,1 & 758,6 & 3011,5 & 790,3 & 392,3 & 471,6 & 1357,3 \\
\hline Ecuador & 1170,3 & 382,1 & 81,1 & 453,0 & 254,2 & 8,8 & $\mathbf{0 , 2}$ & 0,4 & 4,7 & 3,5 \\
\hline Columbia & 626,1 & 241,9 & 40,1 & 110,5 & 233,5 & 5850,8 & 628,2 & 988,4 & 1769,0 & 2465,3 \\
\hline Costa Rica & 213,1 & 102,0 & 43,5 & 22,3 & 45,5 & 265,0 & 19,8 & 3,1 & 0,6 & 241,4 \\
\hline Cuba & 849,6 & 629,7 & 87,5 & 82,8 & 49,7 & 382,9 & 59,9 & 94,8 & 91,2 & 137,0 \\
\hline Mexico & 222,0 & 132,6 & 10,6 & 52,0 & 26,7 & 1380,6 & 304,9 & 257,8 & 276,4 & 541,5 \\
\hline Panama & 51003,9 & 14564,5 & 13055,6 & 11059,8 & 12324,0 & 5794,8 & 1350,8 & 1282,1 & 1428,2 & 1733,7 \\
\hline Peru & 1236,1 & 56,1 & 368,3 & 61,8 & 749,9 & 491,6 & 67,2 & 237,9 & 69,0 & 117,5 \\
\hline Uruguay & 210,4 & 30,8 & 80,6 & 78,3 & 20,7 & 27,2 & 0,1 & 25,0 & 1,7 & 0,4 \\
\hline Chile & 149,5 & 57,3 & 9,0 & 60,0 & 23,3 & 118,2 & 8,6 & 9,1 & 10,8 & 89,7 \\
\hline
\end{tabular}

Source: it is the authors' analysis the dates from Site of State Statistics Service of Ukraine (ukrstat.gov.ua. Retriever from: http://www.ukrstat.gov.ua)

Invests in Ukrainian economy by the countries of the LA is a separate interesting aspect of our investigation. In particular, on the website of the State Statistics Service of Ukraine, certain information is encrypted, as well as data on investment from Brazil or Canada. At the same time, we know from the websites of Ukrainian embassies that Belize is the largest investment partner of Ukraine, followed by Cuba, Panama, and Dominican Republic.

\section{Conclusions}

Despite of the fact that long ago economic contacts served to establish political and diplomatic relations, this trend needs to be adjusted nowadays. Note that, the farther away (geographically) country exists the less you know about it, the less you buy something from this country. Therefore, it is important for Ukraine to promote more about itself, to create a positive image, to offer its goods, services, cooperation in order to improve the state of trade and economic relations with any country whose territory is so far away, that became an obstacle to establishing closer relations with that country. This firstly applies to bilateral relations between Ukraine and Latin America countries. It should be emphasized on such tendency - a higher level of relations between Ukraine and LA exists with countries where a large Ukrainian diaspora (particularly in Brazil and Argentina), because they know more about Ukraine, different cultural and artistic centers, etc., established diplomatic relations.

Based on the above mentioned facts about the activities of the Embassies of Ukraine in the Latin American region, we conclude that Ukrainian economic diplomacy in the Latin American countries is a failure and sometimes has some negative aspects.

Firstly, let us emphasize that Ukraine has only 5 embassies in Latin America, representing Ukrainian national interests in 13 more countries. Thus, Ukraine is more or less represented in 18 countries whereas LA region consist of 33 countries!

Secondly, diplomatic contacts, including economic sphere between Ukraine and Latin American countries, are not systematic, there are failures of two to three years regarding diplomatic meetings and economic contacts. Often diplomatic relations have been established at the beginning of the 21st 
century. Information on the website of embassies is not updated on time, that affects the image of our country, because citizens from other country get official information about Ukraine from the website of the embassy.

Thirdly, if we will analyze the content of Ukrainian embassies' web-sites, for example, in Latin America countries, we can admit negative tendency in informational policy of Ukraine in creating our image abroad. For instance, we inform citizens abroad about the Holodomor of 1932-1933, military events in the East of Ukraine, etc. However, on the one hand, we need to provide objective information about events in Ukraine, but on the other hand, we are forming a negative image of Ukraine as one that has no positives. We will emphasize that countries can receive information about Ukraine from news portals of other countries, which are not always friendly to Ukraine.

Fourthly, analyzing the overall information on export-import operations, we conclude that Ukraine are not fully use its capabilities in cooperation with Latin American countries. Ukraine with many LA countries has a negative balance in trade (Argentina, Brazil, Mexico, Chile, Uruguay, Bolivia, Guyana, Guatemala).

Fifthly, Ukraine does not use in practice such element of economic diplomacy as the staffing of the embassy by experts in the field of economy. Most embassies do not have the position of economic advisor, although the embassies of the leading countries of the world have relevant departments dealing with economic cooperation with the host country. Today, the Ukrainian-Cuban Intergovernmental Commission for Trade, Economic, Scientific and Technical Cooperation, whose last meeting took place in 2010, is functioning, but having a great pause in its work. And for 2017, the VII Intergovernmental Meeting on Trade and Economic Cooperation of Brazil was planned, which never took place. So, our state has certain shortcomings in the organization of diplomatic missions, considering the tendencies of economic diplomacy.

Thus, among the four strategies of economic diplomacy referred by N. Bayne and S. Woolcock, Ukraine uses only one: involvement of high-ranking politicians (ministries) in its work, but partly, because only two intergovernmental trade and economic, scientific and technical commissions have been set up (between Cuba and Ukraine and Brazil and Ukraine). Ukraine does not use such strategies as involvement of non-governmental organizations, private business and civil society. The figures collected and analyzed in the study gave us an opportunity to note that Ukrainian economic policy in the Latin American region is neither active nor systematic economic diplomacy, and demonstrates its failure and low efficiency.

In the next step, after some time, the development of economic diplomacy of Ukraine in the Latin American direction in the context of dynamic changes in Ukraine's foreign policy will be recognized as a part of future research investigation.

\section{References}

Bayne, N., \& Woolcock, S. (2003). The New Economic Diplomacy: Decision-Making and Negotiation in International Economic Relations. Hampshire, England: Ashgate Publising Limited

Brautigam, D., \& Xiaoyang, T. (2012). Economic statecraft in China's new overseas special economic zones: soft power, business or resource security?. International Affairs, 88(4), 799-816.

Embaixada da Ucrania no Brazil (2018). Programa Parlamentos do Mundo da Rádio Senado é dedicado à Ucrânia [Senate Radio World Parliaments Program is dedicated to Ukraine]. Retrieved from https://brazil.mfa.gov.ua/pt/press-center/publications/6o65-radio-senatu-nacionalynogo-kongresubraziliji-prisvyatilo-ukrajini-svoju-programu on February 20, 2019. [in Portuguese].

Embaixada da Ucrania no Brazil. (2017). Entrevista do Embaixador da Ucrânia à Rede Mercosul por ocasião dos 25 anos das relações diplomáticas Ucrânia-Brasil [Interview of the Ambassador of Ukraine to the Mercosur Network on the occasion of 25 years of Ukraine-Brazil diplomatic relations]. Retrieved from https://brazil.mfa.gov.ua/pt/press-center/publications/5312-intervju-posla-ukrajini-rede-mercosul-znagodi-25-ji-richnici-vstanovlennya-diplomatichnih-vidnosin-mizh-ukrajinoju-ta-brazilijeju-movojuoriginalu on February 20, 2019. [in Portuguese]. 
Embaixada da Ucrania no Brazil. (2016). Rostyslav Tronenko: O mercado brasileiro não é um sprint (em ucraniano). [Rostyslav Tronenko: The Brazilian market is not a sprint (in Ukrainian)]. Retrieved from https://brazil.mfa.gov.ua/pt/press-center/publications/4917-rostislav-tronenko-brazilysykij-rinok--ce-nesprint on February 20, 2019. [in Portuguese].

Embahada de Ucrania en los Estados Unidos Mexicanos (n.d.). Propuestas de Empresas Ucranianas. Recuperado de https://mexico.mfa.gov.ua/es/ukraine-mx/trade/proposals on February 2, 2019.[in Spanish].

Embahada de Ucrania en los Estados Unidos Mexicanos (n.d.). Las propuestas comerciales de las regiones de Ucrania. Recuperado de https://mexico.mfa.gov.ua/es/ukraine-mx/trade/investment on February 2, 2019. [in Spanish].

Embassy of Ukraine in the Argentine Republic (2019). Dogovirno-pravova baza mizh Ukrayinoyu ta Argenty'noyu [Legal basis between Ukraine and Argentina]. Retrieved from https://argentina.mfa.gov.ua/ua/ukrainear/legal-acts on February 11, 2019. [in Ukrainian].

Embassy of Ukraine in the Argentine Republic (2019). Polity 'chni vidnosy 'ny' mizh Ukrayinoyu ta Argenty 'noyu [Political relations between Ukraine and Argentina]. Retrieved from https://argentina.mfa.gov.ua/ua/ukraine-ar/diplomacy on February 11, 2019. [in Ukrainian].

Embassy of Ukraine in the Argentine Republic (2019). Torgivel'no-ekonomichne spivrobitny'cztvo mizh Ukrayinoyu ta Argenty'noyu [Trade and economic cooperation between Ukraine and Argentina]. Retrieved from https://argentina.mfa.gov.ua/ua/ukraine-ar/trade on February 11, 2019. [in Ukrainian].

Embassy of Ukraine in the Argentine Republic (n.d.). Mizhregional'ne spivrobitny 'cztvo mizh Ukrayinoyu ta Argenty'noyu [Interregional cooperation between Ukraine and Argentina]. Retrieved from https://argentina.mfa.gov.ua/ua/ukraine-ar/regions on February 12, 2019. [in Ukrainian].

Embassy of Ukraine in the Argentine Republic (n.d.). Kul turno-gumanitarne spivrobitny 'cztvo mizh Ukrayinoyu ta Argenty 'ns 'koyu Respublikoyu [Cultural and humanitarian cooperation between Ukraine and the Argentine Republic]. Retrieved from https://argentina.mfa.gov.ua/ua/ukraine-ar/culture on February 11, 2019. [in Ukrainian].

Embassy of Ukraine in the Argentine Republic (n.d.). Torgivel 'no-ekonomichne spivrobitny 'cztvo mizh Ukrayinoyu ta Chy'li [Trade and economic cooperation between Ukraine and Chile]. Retrieved from https://argentina.mfa.gov.ua/ua/ukraine-chile/trade on February 11, 2019. [in Ukrainian].

Embassy of Ukraine in the Argentine Republic (2012). Dogovirno-pravova baza mizh Ukrayinoyu ta Chy'li [Legal basis between Ukraine and Chile]. Retrieved from: https://argentina.mfa.gov.ua/ua/ukraine-chile/legal-acts [in Ukrainian].

Embassy of Ukraine in the Argentine Republic (n.d.). Kul turno-gumanitarne spivrobitny 'cztvo mizh Ukrayinoyu ta Chy'li [Cultural and humanitarian cooperation between Ukraine and the Chile]. Retrieved from https://argentina.mfa.gov.ua/ua/ukraine-chile/culture on February 12, 2019. [in Ukrainian].

Embassy of Ukraine in the Argentine Republic (2018). Polity 'chni vidnosy 'ny' mizh Ukrayinoyu ta Urugvayem [Political relations between Ukraine and Uruguay]. Retrieved from https://argentina.mfa.gov.ua/ua/ukraineuruguay/diplomacy on February 11, 2019. [in Ukrainian].

Embassy of Ukraine in the Argentine Republic (2018). Torgivel'no-ekonomichne spivrobitny'cztvo mizh Ukrayinoyu ta Urugvayem [Trade and economic cooperation between Ukraine and Uruguay]. Retrieved from https://argentina.mfa.gov.ua/ua/ukraine-uruguay/trade on February 11, 2019. [in Ukrainian].

Embassy of Ukraine in the Argentine Republic (2018). Dogovirno-pravova baza mizh Ukrayinoyu ta Urugvayem [Legal basis between Ukraine and Uruguay]. Retrieved from https://argentina.mfa.gov.ua/ua/ukraineuruguay/legal-acts on February 11, 2019. [in Ukrainian].

Embassy of Ukraine in the Argentine Republic (n.d.). Kul turno-gumanitarne spivrobitny 'cztvo mizh Ukrayinoyu ta Urugvayem [Cultural and humanitarian cooperation between Ukraine and Uruguay]. Retrieved from https://argentina.mfa.gov.ua/ua/ukraine-uruguay/culture on February 11, 2019. [in Ukrainian].

Embassy of Ukraine in the Argentine Republic (2018). Polity 'chni vidnosy'ny' mizh Ukrayinoyu ta Paragvayem [Political relations between Ukraine and Paraguay]. Retrieved from https://argentina.mfa.gov.ua/ua/ukraineparaguay/diplomacy on February 13, 2019. [in Ukrainian].

Embassy of Ukraine in the Argentine Republic (n.d.). Torgivel 'no-ekonomichne spivrobitny 'cztvo mizh Ukrayinoyu ta Paragvayem [Trade and economic cooperation between Ukraine and Paraguay]. Retrieved from https://argentina.mfa.gov.ua/ua/ukraine-paraguay/trade on February 13, 2019. [in Ukrainian].

Embassy of Ukraine in the Argentine Republic (n.d.). Dogovirno-pravova baza mizh Ukrayinoyu ta Paragvayem [Legal basis between Ukraine and Paraguay]. Retrieved from https://argentina.mfa.gov.ua/ua/ukraineparaguay/legal-acts on February 13, 2019. [in Ukrainian]. 
Embassy of Ukraine in the Argentine Republic (n.d.). Kul'turno-gumanitarne spivrobitny 'cztvo mizh Ukrayinoyu ta Paragvayem [Cultural and humanitarian cooperation between Ukraine and Paraguay]. Retrieved from https://argentina.mfa.gov.ua/ua/ukraine-paraguay/culture on February 13, 2019. [in Ukrainian].

Embassy of Ukraine in the Federative Republic of Brazil (n.d.). Polity 'chni vidnosy 'ny' mizh Ukrayinoyu ta Brazy'liyeyu [Political relations between Ukraine and Brazil]. Retrieved from https://brazil.mfa.gov.ua/ua/ukraine-br/diplomacy on February 19, 2019. [in Ukrainian].

Embassy of Ukraine in the Federative Republic of Brazil (n.d.). Dogovirno-pravova baza mizh Ukrayinoyu ta Brazy 'liyeyu [Legal basis between Ukraine and Brazil]. Retrieved from https://brazil.mfa.gov.ua/ua/ukrainebr/legal-acts on February 19, 2019. [in Ukrainian].

Embassy of Ukraine in the Federative Republic of Brazil (n.d.). Torgivel 'no-ekonomichne spivrobitny 'cztvo mizh Ukrayinoyu ta Brazy'liyeyu [Trade and economic cooperation between Ukraine and Brazil]. Retrieved from: https://brazil.mfa.gov.ua/ua/ukraine-br/trade on February 19, 2019. [in Ukrainian].

Embassy of Ukraine in the Federative Republic of Brazil (2018, November, 3). Brazyl's'ki ZMI pro nashe pryynyattya : osvitu vshanuvaly pid chas svyatkuvannya dnya Nezalezhnosti Ukrayiny (movoyu oryhinalu). [Brazilian media about our acceptance: education was honored during the celebration of Independence Day of Ukraine (in the original language)]. Retrieved from https://brazil.mfa.gov.ua/ua/press-center/news/68262brazilysyki-zmi-pro-nashe-prijnyattya--osvitu-vshanuvali-pid-chas-svyatkuvannya-dnya-nezalezhnostiukrajini-movoju-originalu on February 19, 2019. [in Ukrainian].

Embassy of Ukraine in the Federative Republic of Brazil (n.d.). Polity 'chni vidnosy 'ny' mizh Ukrayinoyu ta Boliviyeyu [Political relations between Ukraine and Bolivia]. Retrieved from https://brazil.mfa.gov.ua/ua/ukraine-bolivia/diplomacy on February 20, 2019. [in Ukrainian].

Embassy of Ukraine in the Federative Republic of Brazil (n.d.). Torgivel 'no-ekonomichne spivrobitny 'cztvo mizh Ukrayinoyu ta Boliviyeyu [Trade and economic cooperation between Ukraine and Bolivia]. Retrieved from: https://brazil.mfa.gov.ua/ua/ukraine-bolivia/trade on February 20, 2019. [in Ukrainian].

Embassy of Ukraine in the Federative Republic of Brazil (n.d.). Polity 'chni vidnosy 'ny' mizh Ukrayinoyu ta Gajyanoyu [Political relations between Ukraine and Guyana]. Retrieved from https://brazil.mfa.gov.ua/ua/ukraine-guyana/diplomacy on February 21, 2019. [in Ukrainian].

Embassy of Ukraine in the Federative Republic of Brazil (n.d.). Torgivel 'no-ekonomichne spivrobitny'cztvo mizh Ukrayinoyu ta Gajyanoyu [Trade and economic cooperation between Ukraine and Gayana]. Retrieved from https://brazil.mfa.gov.ua/ua/ukraine-guyana/trade on February 21, 2019. [in Ukrainian].

Embassy of Ukraine in the Federative Republic of Brazil (n.d.). Polity 'chni vidnosy 'ny' mizh Ukrayinoyu ta Surinamom [Political relations between Ukraine and Surinam]. Retrieved from: https://brazil.mfa.gov.ua/ua/surinam/diplomacy on February 21, 2019. [in Ukrainian].

Embassy of Ukraine in the Federative Republic of Brazil (n.d.). Torgivel 'no-ekonomichne spivrobitny 'cztvo mizh Ukrayinoyu ta Surinamom [Trade and economic cooperation between Ukraine and Surinam]. Retrieved from https://brazil.mfa.gov.ua/ua/surinam/trade on February 21, 2019. [in Ukrainian].

Embassy of Ukraine in the Republic of Cuba (n.d.). Polity 'chni vidnosy 'ny ' mizh Ukrayinoyu ta Kuboyu [Political relations between Ukraine and Cuba]. Retrieved from https://cuba.mfa.gov.ua/ua/ukraine-cu/diplomacy on March 2, 2019. [in Ukrainian].

Embassy of Ukraine in the Republic of Cuba (n.d.). Torgivel 'no-ekonomichne spivrobitny'cztvo mizh Ukrayinoyu ta Kuboyu [Trade and economic cooperation between Ukraine and Cuba]. Retrieved from https://cuba.mfa.gov.ua/ua/ukraine-cu/trade on March 2, 2019. [in Ukrainian].

Embassy of Ukraine in the Republic of Cuba (n.d.). Dogovirno-pravova baza mizh Ukrayinoyu ta Dominikanoyu [Legal basis between Ukraine and Dominican Republic]. Retrieved from https://cuba.mfa.gov.ua/ua/ukrainedominicana/legal-acts on March 2, 2019. [in Ukrainian].

Embassy of Ukraine in the Republic of Peru (n.d.). Torgivel 'no-ekonomichne spivrobitny 'cztvo mizh Ukrayinoyu ta Peru [Trade and economic cooperation between Ukraine and Peru]. Retrieved from: https://peru.mfa.gov.ua/ua/ukraine-pe/trade on March 3, 2019. [in Ukrainian].

Embassy of Ukraine in the United Mexican States (n.d.). Polity'chni vidnosy 'ny' mizh Ukrayinoyu ta Meksy 'koyu [Political relations between Ukraine and Mexico]. Retrieved from https://mexico.mfa.gov.ua/ua/ukraine$\mathrm{mx}$ /diplomacy on February 5, 2019. [in Ukrainian].

Embassy of Ukraine in the United Mexican States (n.d.). Vy'stavky' ta yarmarky 'v Meksy 'ci [Exhibitions and fairs in Mexico]. Retrieved from https://mexico.mfa.gov.ua/ua/ukraine-mx/trade/exhibitions on February 5, 2019. [in Ukrainian].

Embassy of Ukraine in the United Mexican States (n.d.). Torgivel'no-ekonomichne spivrobitny'cztvo mizh Ukrayinoyu ta Meksy'koyu [Trade and economic cooperation between Ukraine and Mexico]. Retrieved from https://mexico.mfa.gov.ua/ua/ukraine-mx/trade/trade-info on February 6, 2019. [in Ukrainian]. 
Embassy of Ukraine in the United Mexican States (n.d.). Kul'turno-gumanitarne spivrobitny'cztvo mizh Ukrayinoyu ta Meksy'koyu [Cultural and humanitarian cooperation between Ukraine and Mexico]. Retrieved from https://mexico.mfa.gov.ua/ua/ukraine-mx/culture on February 6, 2019. [in Ukrainian].

Embassy of Ukraine in the United Mexican States (n.d.). Polity 'chni vidnosy'ny' mizh Ukrayinoyu ta Kosta-Rikoyu [Political relations between Ukraine and Costa Rica]. Retrieved from https://mexico.mfa.gov.ua/ua/ukrainecosta-rica/diplomacy on February 6, 2019. [in Ukrainian].

Embassy of Ukraine in the United Mexican States (n.d.). Torgivel'no-ekonomichne spivrobitny'cztvo mizh Ukrayinoyu ta Kosta-Rikoyu [Trade and economic cooperation between Ukraine and Costa Rica]. Retrieved from: https://mexico.mfa.gov.ua/ua/ukraine-costa-rica/trade on February 6, 2019. [in Ukrainian].

Embassy of Ukraine in the United Mexican States (n.d.). Torgivel'no-ekonomichne spivrobitny'cztvo mizh Ukrayinoyu ta Gvatemaloyu [Trade and economic cooperation between Ukraine and Guatemala]. Retrieved from https://mexico.mfa.gov.ua/ua/ukraine-guatemala/trade on February 8, 2019. [in Ukrainian].

Embassy of Ukraine in the United Mexican States (n.d.). Torgivel'no-ekonomichne spivrobitny'cztvo mizh Ukrayinoyu ta Panamoyu [Trade and economic cooperation between Ukraine and Panama]. Retrieved from https://mexico.mfa.gov.ua/ua/ukraine-panama/trade on February 8, 2019. [in Ukrainian].

Embassy of Ukraine in the United Mexican States (n.d.). Torgivel'no-ekonomichne spivrobitny'cztvo mizh Ukrayinoyu ta Belizom [Trade and economic cooperation between Ukraine and Belize]. Retrieved from: https://mexico.mfa.gov.ua/ua/ukraine-belice/trade on February 8, 2019. [in Ukrainian].

Embassy of Ukraine in the United Mexican States (n.d.). Torgivel'no-ekonomichne spivrobitny'cztvo mizh Ukrayinoyu ta Kosta Rikoyu [Trade and economic cooperation between Ukraine and Costa Rica]. Retrieved from: https://mexico.mfa.gov.ua/ua/ukraine-costa-rica/trade on February 6, 2019. [in Ukrainian].

Embassy of Ukraine in the United Mexican States (n.d.). Polity 'chni vidnosy 'ny ' mizh Ukrayinoyu ta Panamoyu [Political relations between Ukraine and Panama]. Retrieved from https://mexico.mfa.gov.ua/ua/ukrainepanama/diplomacy on February 9, 2019. [in Ukrainian].

Embassy of Ukraine in the United Mexican States (n.d.). Torgivel'no-ekonomichne spivrobitny'cztvo mizh Ukrayinoyu ta Panamoyu [Trade and economic cooperation between Ukraine and Panama]. Retrieved from https://mexico.mfa.gov.ua/ua/ukraine-panama/trade on February 9, 2019. [in Ukrainian].

Flissak, K. (2013). Formy' ta metody' ekonomichnoyi dy'plomatiyi u sferi torgovel'no-ekonomichnogo ta investy' cijnogo spivrobitny'cztva [Forms and methods of economic diplomacy in the field of trade, economic and investment cooperation]. Ekonomichny ' $j$ analiz. - Journal of Economic Analysis, 12(1), 306310. Retrieved from http://nbuv.gov.ua/UJRN/ecan_2013_12\%281\%29_65 on February 2, 2019. [in Ukrainian].

Isachenko, T.M. (2015). Ekonomicheskaya diplomatiya v usloviyah politicheskogo krizisna [Economic diplomacy in a political crisis]. Vestnik SPbGU - Bulletin of St. Petersburg State University, Vol. 5, 3, 46-64. Retrieved from https://cyberleninka.ru/article/v/ekonomicheskaya-diplomatiya-v-usloviyah-politicheskogo-krizisa on February 2, 2019. [in Russian].

Juma, C. (2013, February, 26). Africa and Brazil at the Dawn of New Economic Diplomacy. Belfer Center for Science and International Affairs. Retrieved from https://www.belfercenter.org/publication/africa-and-brazil-dawnnew-economic-diplomacy on February 3, 2019.

Kolyada, O.V., \& Rajcheva, A.A. (2018). Ukrayins' ka diaspora yak faktor pogly'blennya zovnishn 'oekonomichny'x vidnosy'n krayiny' [The Ukrainian Diaspora as a Factor for Deepening the Country's Foreign Economic Relations]. Ekonomika $i$ suspil'stvo - Economy and society Journal, 15, 33-39. Retrieved from http://economyandsociety.in.ua/journal/15_ukr/6.pdf on February 2, 2019. [in Ukrainian].

Kukharenko R. (2016). Latyns'ka Ameryka v heopolitychnykh realiyakh suchasnoho svitu [Latin America in the geopolitical realities of the modern world]. Hlobal Analityk - Global Analityk web-site. Retrieved from http://www.global-analityk.com/аналітика/латинська-америка-в-геополітичних-ре/ on February 2, 2019. [in Ukrainian].

La Embajada de la República Argentina en Ucrania. (n.d.). Programa_Días de la Cultura Argentina en Kiev [Programa_Dias de la Cultura Argentina in Kiev]. Retrieved from http://www.eucra.cancilleria.gov.ar/userfiles/programa_D\%C3\%ADas\%2ode\%2ola\%2oCultura\%2oArgentin a\%20en\%2oKiev.pdf on February 11, 2019. [in Spanish].

La Embajada de la República Argentina en Ucrania. (2016). Foro de inversion y negocios de Argentina [Argentina business and investment forum]. Retrieved from: https://eucra.cancilleria.gob.ar/userfiles /EXECUTIVE\%20SUMMARY_ESP_13.pdf on February 11, 2019. [in Spanish].

Lee, D., \& Hocking, B. (2010). Economic Diplomacy. In Robert A. Denemark (ed.), The International Studies Encyclopedia, Vol. II, (pp. 1216-1227). 
Lehendarnyy litak "Mriya" povernuvsya v Ukrayinu pislya naydovshoho vidryadzhennya [The legendary plane "Mriya" has returned to Ukraine after the longest business trip]. (2018, 3 August). Tsn.ua. Retrieved from https://tsn.ua/ukrayina/legendarniy-litak-mriya-povernuvsya-v-ukrayinu-pislya-naydovshogovidryadzhennya-1196409.html on March 15, 2019. [in Ukrainian].

Litak-hihant "Mriya" realizuvav rekordnyy proekt perevezennya v Pivdenniy Amerytsi [Plane giant "Mriya" has implemented a record project of transportation in South America]. (2018, 27 July). Tsn.ua. Retrieved from: https://tsn.ua/ukrayina/litak-gigant-mriya-realizuvav-rekordniy-proekt-perevezennya-v-pivdenniy-americi1192581.html on March 15, 2019. [in Ukrainian].

Manasserian, T. (2017, October). Economic diplomacy: from theory to real life. ResearchGate. Retrieved from https://www.researchgate.net/publication/320274277_Economic_diplomacy_from_theory_to_real_life on February 18, 2019.

Nyzhnyk, V. M. (2007). Ekonomichna dyplomatiya ta ekonomichna bezpeka Ukrayiny: Navchal'nyy posibnyk [Economic Diplomacy and Economic Security of Ukraine: A Handbook]. Khmel'nyts'kyy: KhNU. Retrieved from https://moodle.znu.edu.ua/pluginfile.php?file=/254494/mod_resource/content/1pdf on February 18, 2019. [in Ukrainian].

Sajt derzhavnoyi sluzhby' staty'sty'ky' Ukrayiny' [Site of the Ukrainian State Statistic Service]. ukrstat.gov.ua. Retriever from http://www.ukrstat.gov.ua on March 20, 2019. [in Ukrainian].

Saner, R., \& Yiu, L. (2003). International Economic Diplomacy: Mutations in Post-modern Times. S. Mawby (Ed.). Netherlands Institute of International Relations "Clingendael"

Skandal s ukrainskim posolstvom: meksikantsyi rasskazali pro neofitsialnyie "vznosyi" za vizyi [Scandal with the Ukrainian embassy: Mexicans talked about unofficial "fees" for visas]. (2019). tsn.ua. Retrieved from https://ru.tsn.ua/ukrayina/skandal-s-ukrainskim-posolstvom-meksikancy-rasskazali-pro-neoficialnyevznosy-za-vizy-1277898.html on March 16, 2019. [in Russian].

State Statistics Service of Ukraine. (2018). Heohrafichna struktura zovnishn'oyi torhivli tovaramy u sichni-lystopadi 2018 roku [Geographic structure of foreign trade in goods in January-November 2018]. Retrieved from http://www.ukrstat.gov.ua/ on March 20, 2019. [in Ukrainian].

Storinka Argenty'ns'kogo Domu u Fejsbuk [The official page "Argentina house in Ukraine" in Facebook ]. Retrieved from https://www.facebook.com/Casa-Argentina-en-Ucrania-1680168382201810/?ref=tn_tnmn on March 22, 2019. [in Ukrainian].

Szatlach, M. E. (2015). The importance of economic diplomacy in the era of globalization (the case of China). Swiat Idei i Polityki, Tom 14 (26). Retrieved from: https://repozytorium.ukw.edu.pl/bitstream/handle/item/420o /The\%2oimportance\%2oof\%2oeconomic\%2odiplomacy\%2oin\%2othe\%2oera\%2oof\%2oglobalization\%2othe \%20case\%20of\%2oChina.pdf?sequence=1\&isAllowed=y on February 12, 2019.

Tatarenko, N.O. (2005). Ekonomichna dy’plomatiya: svitovy'j dosvid ta ukrayins'ki zdobutky’ (polity'koekonomichny'j aspekt) [Economic Diplomacy: World Experience and Ukraine's Achievements (PoliticoEconomic Aspect)]. Naukovy'j visny'k Dy'plomaty 'chnoyi akademiyi Ukrayiny' - Scientific Bulletin of the Diplomatic Academy of Ukraine, 22 (2), 4-9. [in Ukrainian].

Ukaz Prezy`denta Ukrayiny' Pro Strategiyu stalogo rozvy'tku “Ukrayina - 2020" [Presidential Decree on Ukraine 2020 Sustainable Development Strategy]. (2015). https://zakon.rada.gov.ua. Retrieved from https://zakon1.rada.gov.ua/laws/show/5/2015 on February 4, 2019. [in Ukrainian].

Ukraina otkryila pervoe dippredstavitelstvo v Chili [Ukraine opened the first diplomatic mission in Chile]. (2018). BezTabu.net. Retrieved from https://beztabu.net/novosti_t 4952 on March 18, 2019. [in Russian].

UN. (n.d.). Country classification. Retrieved from https://www.un.org/en/development/desa/policy/wesp /wesp_current/2014wesp_country_classification.pdf on February 3, 2019.

Varnalij, Z. S., Ony'shhenko, S. V., \& Maslij, O. A. (2016). Mexanizm poperedzhennya zagroz ekonomichnij bezpeci Ukrayiny' [Mechanism for preventing threats to the economic security of Ukraine]. Ekonomichny' $j$ chasopy's-XXI. - The Economic Annals-XXI Journal, 159, 20-25. Retrieved from http://nbuv.gov.ua/UJRN/ecchado_2016_159_5 on February 20, 2019. [in Ukrainian].

Zakon Ukrayiny' Pro nacional 'nu bezpeku Ukrayiny' [ Law of Ukraine On National Security of Ukraine]. (2018). https://zakon.rada.gov.ua. Retrieved from https://zakon.rada.gov.ua/laws/show/2469-19 on February 4, 2019. [in Ukrainian].

Zakon Ukrayiny' Pro zasady' vnutrishn oyi i zovnishn`oyi polity'ky' [ Law of Ukraine On the Principles of Domestic and Foreign Policy]. (2018). https://zakon.rada.gov.ua. Retrieved from https://zakon.rada.gov.ua/laws/show/2411-17 on February 4, 2019. [in Ukrainian]. 